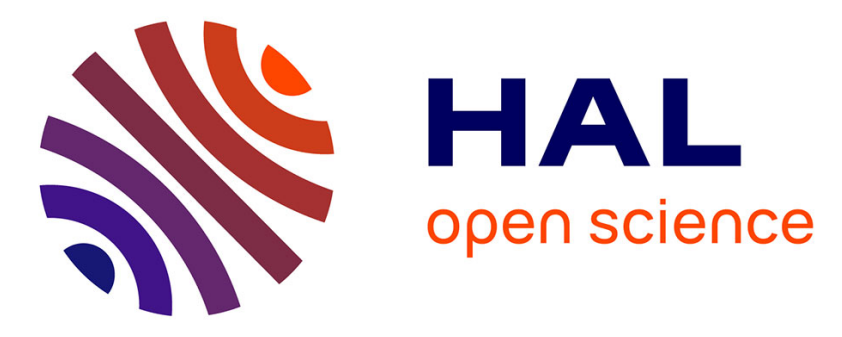

\title{
Rain, Wind, and Dust Connections in the Sahel
}

Gilles Bergametti, Jean-Louis Rajot, B. Marticorena, A. Féron, C. Gaimoz, B.

Chatenet, M. Coulibaly, I. Koné, A. Maman, A. Zakou

\section{To cite this version:}

Gilles Bergametti, Jean-Louis Rajot, B. Marticorena, A. Féron, C. Gaimoz, et al.. Rain, Wind, and Dust Connections in the Sahel. Journal of Geophysical Research: Atmospheres, 2022, 127 (3), pp.e2021JD035802. 10.1029/2021JD035802 . hal-03553552

\section{HAL Id: hal-03553552 \\ https://hal.science/hal-03553552}

Submitted on 2 Feb 2022

HAL is a multi-disciplinary open access archive for the deposit and dissemination of scientific research documents, whether they are published or not. The documents may come from teaching and research institutions in France or abroad, or from public or private research centers.
L'archive ouverte pluridisciplinaire HAL, est destinée au dépôt et à la diffusion de documents scientifiques de niveau recherche, publiés ou non, émanant des établissements d'enseignement et de recherche français ou étrangers, des laboratoires publics ou privés. 


\section{Rain, Wind and Dust Connections in the Sahel}

\section{G. Bergametti ${ }^{1}$, J.-L. Rajot ${ }^{1,2}$, B. Marticorena ${ }^{3}$, A. Féron ${ }^{1}$, C. Gaimoz ${ }^{3}$, B. Chatenet ${ }^{1}$, M. Coulibaly ${ }^{4}$, I. Koné ${ }^{4}$, A. Maman ${ }^{5}$ and A. Zakou ${ }^{5}$}

\footnotetext{
${ }^{1}$ LISA (Laboratoire Interuniversitaire des Systèmes Atmosphériques), Université de Paris and Univ Paris Est Creteil, CNRS, F-75013 Paris, France

${ }^{2}$ iEES Paris (Institut d'Ecologie et des Sciences de l'Environnement de Paris), UMR IRD 242, Univ Paris Est Creteil-Sorbonne Université-CNRS-INRA-Université de Paris, Bondy, France

${ }^{3}$ LISA (Laboratoire Interuniversitaire des Systèmes Atmosphériques), Univ Paris-Est-Creteil and Université de Paris, CNRS, F-94010 Créteil, France

${ }^{4}$ Institut d'Economie Rurale (IER) Station de Recherche Agronomique de Cinzana,, Bamako, Mali.

${ }^{5}$ Institut de Recherche pour le Développement (IRD), IRD-Niamey, Niger.

Corresponding author: Gilles Bergametti (gilles.bergametti@lisa.ipsl.fr)
}

\section{Key Points:}

- During the Sahelian rainy season, the intensity of the strongest wind speed is linked to the intensity of the cold pools

- Most of the strongest wind speed occur just before or just after a rain event starts leading to efficient and intense dust emission

- The highest dust concentration is recorded during May-June when the wind speed is the strongest and the vegetation cover is the lowest 


\section{Abstract}

The Sahel is a dust source region where dust emission could be drastically modified in the future due to climatic and land use changes. Based on observations of meteorological parameters and dust concentration for about 1000 rain events, we investigated the processes leading to dust emission during the rainy season when Mesoscale Convective Systems (MCSs) regularly cross the Sahel. We show that the highest wind speed is strongly linked to the MCS cold pool intensity, which is characterized by a drop in surface temperature. This is observed during the pre-monsoon period ( $\sim$ May-June) when the mid-troposphere is still sufficiently dry to allow intense evaporation of raindrops. Because this coincides with the time of the year that the surface is the least protected by the vegetative residue, the premonsoon wind speed leads to the highest observed dust concentration in our record. Most of the highest wind speed occur before or just at the beginning of a rainy event allowing a large part of the dust raised to be transported ahead the rain limiting dust removal by wet scavenging. Finally, we show that the number of 5-minute dust concentration higher than $5000 \mu \mathrm{g} \mathrm{m}^{-3}$ is almost only occurring during the rainy season. These results suggest that until the dust models fail to correctly resolve MCS, it will be difficulty to obtain reliable estimates of dust emission from the Sahel for the present or future scenarios.

\section{Introduction}

Between 1000 and $4000 \mathrm{Tg}$ of mineral dust are injected yearly by wind erosion into the atmosphere (e.g., Boucher et al., 2013; Huneeus et al., 2011), making dust as one of the most emitted particulate species. As a consequence, the dust cycle has significant impacts on the Earth's environment and is now recognized as a key actor in the Earth System Science (e.g., Shao et al., 2011). In dust source regions, mainly arid and semi-arid areas, the movement of windblown sediments modulates the geomorphology of landscapes (e.g., Greeley \& Iversen, 1985; Livingstone \& Warren, 1996) and can also lead to an impoverishment of naturally vegetated areas and cultivated soils (e.g., Li et al., 2007; 2008; Sterk, 2003; Sterk et al., 1996). During their transport in the atmosphere, the finest component of dust (particles smaller than about $20 \mu \mathrm{m}$ in diameter) can interact with solar and terrestrial radiation, affecting the Earth radiation budget (e.g., Miller et al., 2014; Sokolik et al., 2001). Mineral dust could also act in the formation of clouds, especially as ice nuclei (e.g., DeMott et al., 2003a, 2003b; Sassen et al., 2003) or modifying their microphysical and optical properties (e.g., Knopf \& Koop, 2006; Min et al., 2009; Weinzierl et al., 2017). In deposition areas, dust provides terrestrial and oceanic ecosystems with key nutrients or micronutrients such as phosphorus or iron (e.g., Bergametti et al., 1992; Jickells et al., 2005; 2014; Mahowald et al., 2008; Okin et al., 2004).

The main processes controlling the dust cycle on Earth are very sensitive to meteorological parameters such as surface wind speed and precipitation. Thus, it is suspected that climate change could significantly modify the atmospheric dust content in the future, especially by changing the intensity and location of the dust emissions. The semi-arid regions that are climatic transitional zones should be particularly affected. In these regions, the expected changes should concern not only the meteorological parameters that directly drive dust emission but also those controlling the vegetation cover such as precipitation and evapotranspiration. In addition, the fringes of the arid regions are inhabited, with a population density growing rapidly (e.g., Garenne, 2016; UNDP, 2015). Therefore, it can be expected that land use activities may intensify in the future to provide the food necessary to support this expanding population (e.g., van Vliet et al., 2013). As a consequence, surface cover and 
its temporal dynamics should be strongly modified by transforming naturally vegetated surfaces into crops and/or by changing the pasture pressure exerted on the grazing lands.

Among the semi-arid regions, the Sahelian belt is suspected to be one of the areas where the most significant changes in dust emission could occur in the future. Unfortunately, Global Climate Models (GCM) show very large uncertainties in the projected precipitation trend for this region and do not agree on the amplitude of the change in temperature (e.g., Douville et al., 2006; Monerie et al., 2020). Regional climate models (RCM) do not provide a much more reliable assessment, mainly because the Sahelian climate is strongly influenced by interactions between large, meso and small scales processes that even RCM cannot reproduce satisfyingly (e.g., Dosio \& Panitz, 2016; Dosio et al., 2019). However, recently, the results of a large ensemble of RCMs converge to suggest that, in the future, the precipitation frequency may decrease while the precipitation intensity increases over the Sahel with possible differences between Western and Central Sahel (Dosio et al., 2020).

In the Sahel, dust emission is mainly linked to two main meteorological phenomena depending on the season. During the dry season ( November to April), the Sahel is subject to the Harmattan regime, i.e., the continental northeast trade wind blowing over the North Africa. The surface wind direction up to about $3 \mathrm{~km}$ height is northeasterly and brings hot and dry Saharan air masses into the Sahel. At this period of the year, the strongest surface wind speed occurs between 8:00-12:00 UTC as the result of the morning breakdown of the Nocturnal Low Level Jet (NLLJ), a jet stream whose maximum speed is generally located at $\sim 400 \mathrm{~m}$ above ground level (agl) (e.g., Lothon et al., 2008). A wind speed maximum generally develops after sunset in a layer decoupled from the surface as the consequence of the stable stratification induced by the radiative cooling. In the morning, from sunrise to about midday, the surface heating increases the turbulence that induces a downward mixing of momentum from the NLLJ. By midday, the turbulence reaches its maximum reducing the vertical gradient of momentum and finally progressively dissipating the jet. This leads to surface wind speed generally not higher than $10 \mathrm{~m} \mathrm{~s}^{-1}$ but sufficiently strong to initiate a moderate aeolian erosion (e.g., Rajot et al., 2008).. This morning wind speed enhancement is also observed during the rainy season. However, the wind direction is opposite due to the monsoon flow that blows in the lower atmospheric layer at that time and the associated wind speed is weaker than during the dry season (Figure 1) and the transition period from dry to wet season also called the moistening period. Such phenomena affect not only the Sahel but a large part of Africa, as shown by the pioneer work performed in Sudan by Sutton (1923), further generalized by Tetzlaff (1982) and also reported latter by various authors (e.g., Fiedler et al., 2013; Knippertz, 2008; Lothon et al., 2008). Thus, during the dry season, the Sahelian climate can be viewed as stationary in the sense defined by Abu Bakr \& Wieringa (1988) from observations in Sudan, i.e., the day-to-day variations of the key meteorological parameters are very small and the average diurnal cycle shows a similar behavior all across the region. In terms of dust concentration, it must be noted that the highest monthly and daily mean $\mathrm{PM}_{10}$ concentrations are recorded between February and April. They are mainly due to frequent synoptic transport events of Saharan dust in the Harmattan flow (Kaly et al. 2015; Klose et al., 2010; Marticorena et al., 2010).

Intense rains appear near the Gulf of Guinea in March-April while the Inter-Tropical Convergence Zone (ITCZ) is located between $5^{\circ}$ and $10^{\circ} \mathrm{N}$. Then, the ITCZ moves to $20^{\circ} \mathrm{N}$ in August when the monsoon is fully developed (e.g., N'Tchayi Mbourou et al., 1997). It starts its retreat southward, generally after mid-September. Obviously, intense air masses conflicts can occur along the Inter-Tropical Front as the result of the contrast between the low-level moist southwesterly monsoon flow and the mid-tropospheric dry northeasterly Harmattan air mass. Indeed, during the moistening and monsoon periods, the surface heating 
during daytime can be sufficient to promote the growth of the boundary layer leading to an inversion of the flow in the lower layers. This favors the wind convergence in the humid lower layers, reinforcing the vertical wind shear and the atmospheric instability and finally allowing the formation of convective cells. When such individual convective cells joint together in a more or less organized structure, they form a Mesoscale Convective System (MCS). Such an organization is favored when the vertical mixing extends across the free troposphere and is accompanied by a disturbance of the mid-tropospheric African Easterly waves (e.g., Diedhiou et al., 1999; Mekonen and Rossow, 2018; Semunegus et al., 2017; Vizy \& Cook, 2017).

Up to $95 \%$ of the rainfall over the Sahel is associated with MCSs (e.g., d'Amato \& Lebel, 1998; Dhonneur, 1981; Laing et al., 1999; Laurent et al., 1998; Mohr, 2004). However, in the region of Niamey (Niger), Mathon et al. (2002) distinguished the so-called Organized Convective Systems among the MCSs they have studied. These are large, well-organized and fast-moving MCSs such as squall lines. This type of MCSs accounts for only $12 \%$ of the total number of MCSs, but they contribute to about $90 \%$ of the rainfall.

The cooling caused by phase changes in precipitation falling through the unsaturated Sahelian dry troposphere enhances the formation of a downdraft that is colder and denser than the surrounding air. At the surface, a cold pool is thus formed and propagates in the form of a density current. The winds associated with this cold pool are often gusty (e.g., Roberts \& Knippertz, 2012; Tetzlaff \& Peters, 1988a, 1988b; Vizy \& Cook, 2017). MCSs are most of the time mature and more or less well organized in the evening and during early night (e.g., Mathon et al., 2002; Vizy \& Cook, 2017). Their lifetime ranges from a few hours to about two days, allowing travel paths ranging from 200 to $2000 \mathrm{~km}$ (e.g., Devynck, 1981; Roca et al., 2014).

In areas where soils are easily erodible, the strong vertical wind shear associated with gust fronts of MCSs promotes the uplift of huge amounts of dust ahead these fronts leading to the famous and impressive walls of dust called "haboobs" that can extend vertically up to $5000 \mathrm{~m}$ agl (e.g., Williams, 2008; Williams et al., 2009). As a consequence, during the Sahelian wet season, there is a strong interconnection between precipitation, high wind speed and dust emission.

The respective contributions of the breakdown of the NLLJ and MCSs to dust emission have been examined quantitatively using the Dust Uplift Potential (DUP), a proxy used to quantify the capability of wind to produce wind erosion and dust emission (Fryberger et al., 1979; Marsham et al., 2011). Bergametti et al. (2017) showed that the passing of MCSs is responsible for most of the DUP in the Central Sahel. Similar conclusions were drawn for the Central Sahara for which at least half of dust emission in summer has been estimated to be due to MCSs (Allen et al., 2015; Marsham et al., 2013).

The spatial resolution of large-scale meteorological models is generally suitable to simulate synoptic events but they cannot resolve correctly mesoscale updrafts and downdrafts that are responsible for most of the highest dust emissions in many areas (e.g., Bukowski \& van den Heever, 2020; Pantillon et al., 2016). In particular, these models are unable to simulate the dust events associated with MCSs, mainly because their parameterization of the convection does not represent correctly the density currents and their propagation (e.g., Garcia-Carreras et al., 2013; Largeron et al., 2015; Marsham et al., 2011).

Few observational studies of these events for the Sahel are available even if the intensive observation periods of the AMMA (African Monsoon Multidisciplinary Analyses) program have allowed thorough investigation of selected convective events using radar data, airborne 
measurements and/or surface observations, satellite tracking, etc. (Bou Karam et al., 2009; Chong, 2010; Dione et al., 2014; Flamand et al., 2009; Lothon et al., 2011; McGraw-Herdeg, 2010; Provod et al., 2016; Rickenbach et al., 2009; Tetzlaff and Peters, 1988a, 1988b; Vizy \& Cook, 2017). Most of these detailed observations concern MCSs passing in the region of Niamey during summer 2006 and the number of documented cases remains relatively small, not exceeding a few dozens. Moreover, very few of these studies (e.g., Bou Karam et al., 2008; Crumeyrolle et al., 2008) examined the impact of such events on the atmospheric dust content, most of them being dedicated to the study of the genesis and meteorological characteristics of the convective systems.

In the present paper, we investigate specifically the links between wind speed, precipitation and dust concentration during the Sahelian wet season by using measurements of surface meteorological parameters and dust concentration for more than 1000 rainy events over a 10 year period from two Sahelian stations.
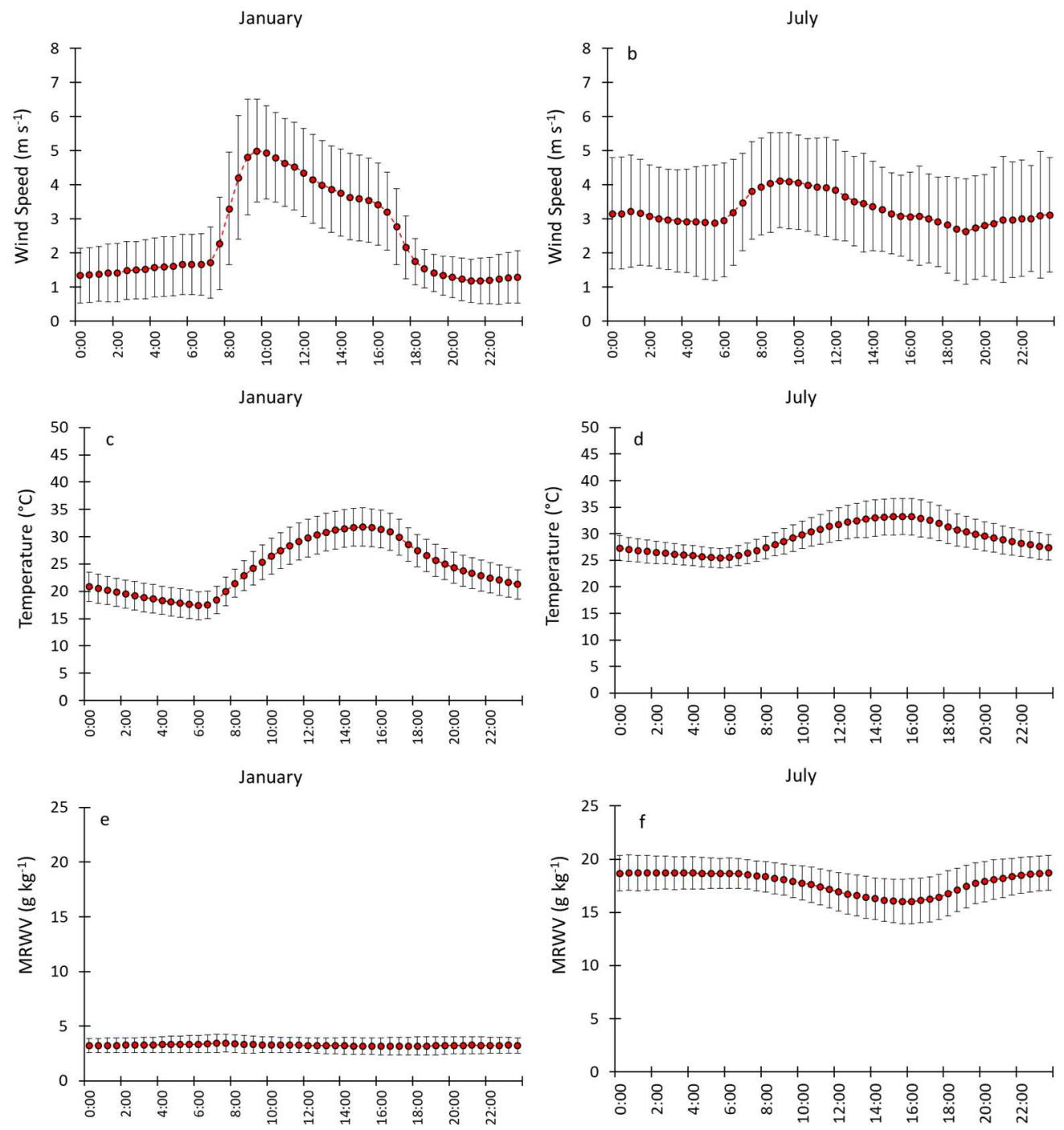

Figure 1. The diurnal cycle of ( $a, b)$ wind speed, $(c, d)$ temperature, $(e, f)$ water vapor mixing ratio at Banizoumbou (Niger) in (a, c, e) January (dry season) and (b, d, f) July (rainy season). Data are averaged over the period 2006-2015. Bars indicate the standard deviation over the ten years. 


\section{Data and Methods}

\subsection{Data}

Continuous measurements of $\mathrm{PM}_{10}$ (Particulate Matter having an aerodynamic diameter $<10$ $\mu \mathrm{m})$ and meteorological parameters were recorded from 2006 to 2015 in two monitoring stations located in Banizoumbou (Niger, $13.54^{\circ} \mathrm{N}, 2.66^{\circ} \mathrm{E}$ ) and Cinzana (Mali, $13.28^{\circ} \mathrm{N}$, $5.93^{\circ} \mathrm{W}$ ). These stations are components of the so-called Sahelian Dust Transect (SDT; Marticorena et al., 2010) that is now included in the INDAAF network (International Network to study Deposition and Atmospheric chemistry in AFrica).

The Banizoumbou station is in a field that has been fallow for more than 25 years, set among traditional fallow/fields. It is located about $2.5 \mathrm{~km}$ from the village of Banizoumbou $(60 \mathrm{~km}$ east of Niamey). The Cinzana station, located about $40 \mathrm{~km}$ east-southeast of Segou, is inside the Institut d'Economie Rurale (IER), $1.5 \mathrm{~km}$ away from the main buildings of the Station de Recherche Agronomique de Cinzana (SRAC). In this area, the vegetation cover is mainly composed of shrubs and trees.

Meteorological measurements are performed at $6.5 \mathrm{~m}$ agl in Banizoumbou and at $2.3 \mathrm{~m}$ agl in Cinzana. A Windsonic 2-D anemometer (Gill ${ }^{\circledR}$ Instruments Ltd.) provides the wind speed and direction averaged over a 5-minute time step. Within each 5-minute period, the 1-second windspeed (sampled every 10 seconds) and hereafter called the "wind gust", was also recorded in 2007, 2008, 2009, 2010, 2011 and 2013 in Banizoumbou and from 2007 to 2012 (included) in Cinzana. Both in Banizoumbou and Cinzana, the wind gusts are well linearly correlated $\left(r^{2}>0.9\right)$ with the 5-minute averaged wind speed with a slope of 1.51 and 1.76 , respectively (Figure S1). This suggests that the wind speed averaged over 5 minutes can be considered as a good proxy for wind gust. It can also be noted that wind gust can reach values as high as $35 \mathrm{~m} \mathrm{~s}^{-1}$ and $22 \mathrm{~m} \mathrm{~s}^{-1}$ in Banizoumbou and Cinzana, respectively.

Rainfall is monitored using an ARG100 aerodynamic tipping bucket rain gauge (Campbell ${ }^{\circledR}$ Scientific Instruments). It provides a contact closure at each tipping (i.e., for each $0.2 \mathrm{~mm}$ of rainfall) and the number of tips is cumulated over a 5-minute time step. Temperature and relative humidity are measured using a 50Y or HMP50 sensor $\left(\right.$ Vaisala $\left.^{\circledR}\right)$. Data acquisition is performed using a CR200X Campbell ${ }^{\circledR}$ Scientific Instruments data logger. The energy is provided by solar panels.

In this paper, we used the 5-minute data for the period 2006-2015. The annual recovery rates for meteorological measurements are given in Table S1. They were always greater than $90 \%$. However, data are lacking for more or less long periods during the rainy season of certain years and thus, these years (2008, 2012, 2014 for Banizoumbou and 2007, 2011, 2013 for Cinzana) have been used when discussing the general characteristics of the rainy events but were excluded to study seasonal or interannual patterns.

Atmospheric concentration of $\mathrm{PM}_{10}$ is measured at $6.5 \mathrm{~m}$ agl at both stations using a Tapered Element Oscillating Microbalance (TEOM 1400A from Thermo Scientific ${ }^{\circledR}$ ) equipped with a $\mathrm{PM}_{10}$ inlet. This instrument allows measurement of particulate concentration ranging from a few micrograms to a few grams per cubic meter. The main element in the instrument is an oscillating element on top of which is located a filter. The particles collected on the filter increase the mass of the oscillating element and thus decrease its oscillation frequency. To maintain a constant confidence level in the particulate concentration measurements, the filters are changed two or three times a month. More details on the $\mathrm{PM}_{10}$ measurements can be found in Marticorena et al., 2010 and Kaly et al., 2015. The annual recovery rates for $\mathrm{PM}_{10}$ measurements ( $>67 \%$ excepted in 2013 in Banizoumbou) are given in Table S1. 


\subsection{Data Selection}

The aim of this paper being to investigate the link between rainy events, wind speed and $\mathrm{PM}_{10}$ concentration, we selected all the measurements performed within the time period ranging from 90 minutes before and 90 minutes after the onset of a rainy event.

The onset and the end of a rainy event are defined as the 5-minute intervals during which occur the first and last bucket tippings of a rainy event, respectively. We also define a rainy event as a precipitation event having a cumulative rainfall strictly greater than $0.2 \mathrm{~mm}$. Records of precipitation not exceeding $0.2 \mathrm{~mm}$ are, for the most part, due to dew, especially those occurring in the morning during the rainy season. Two consecutive rainy events must be separated by a period of time longer than 3 hours. This means that periods of less than 3 hours without recording precipitation can occur inside a rainy event and that a precipitation occurring more than 3 hours after the end of a rainy event is considered as a new rainy event. We define the duration of a rainy event as the delay between the first tipping of the precipitation sensor and the last one, i.e., the tipping not followed by another tipping during the following 3 hours.

Using these criteria, 589 rainy events were identified in Cinzana over the 10 years (449 when 2007, 2011 and 2013 were excluded). In Banizoumbou, 431 rainy events were recorded over the same period (304 when 2008, 2012 and 2014 were excluded). Moreover, $\mathrm{PM}_{10}$ concentration was available for 343 (in Banizoumbou) and 277 (in Cinzana) of these rainy events. In the following, the onset of the rainy event will be used as a reference time, because it is the most easily determined and also because dust concentration can be significantly different before and after the rain starts.

\subsection{DUP}

We use the DUP as an indicator the efficiency of wind to generate dust. As mentioned before, DUP is derived from a quantitative expression of the horizontal flux of windblown sediment initially proposed by Kawamura (1964), tested by White (1979) and adapted by Marsham et al. (2011):

$$
D U P=u^{3}\left(1+u_{t} / u\right)\left(1-u_{t}^{2} / u^{2}\right) \quad \text { for } u>u_{t}
$$

and 0 otherwise;

where $u$ the wind speed at a given height and $u_{t}$ the threshold wind velocity (TWV), i.e. the minimum wind speed required to initiate wind erosion and dust emission. In its original formulation, Kawamura (1964)' formula was expressed in wind friction velocity, $u_{*}$, instead of wind velocity. As mentioned by Marsham et al. (2011), the use of $u$ instead of $u_{*}$ neglects the effects of atmospheric stability on dust lifting. In this paper, we used constant TWVs similar to those used for the same sites by Bergametti et al. (2017) (i.e., $7 \mathrm{~m} \mathrm{~s}^{-1}$ for Banizoumbou and $5.5 \mathrm{~m} \mathrm{~s}^{-1}$ for Cinzana). Using constant TWVs over time and space (and thus a constant roughness length) allows to isolate the role of the meteorology from that of the land surface in dust emission.

\section{Results}

3.1 General Characteristics of the Rainy Events in the Central Sahel 
Figure 2 illustrates the general characteristics of the rainy events recorded in Banizoumbou and Cinzana. The mean rainfall is 581(+/-51) $\mathrm{mm}$ in Cinzana and $440(+/-100) \mathrm{mm}$ in Banizoumbou. The average annual number of rainy events is 64 and 43 in Cinzana and Banizoumbou, respectively. The seasonality of precipitation is well-marked with most of the rainy events (69.7\% and $71.8 \%$ in Cinzana and Banizoumbou, respectively) and the largest part of the rainfall (73.1\% and 84,6\% in Cinzana and Banizoumbou, respectively) occurring in July, August and September. However, the period corresponding to the pre-monsoon is not negligible, especially in Cinzana for which April, May and June contribute for more than $20 \%$ to both the rainfall and the annual number of rainy events. The seasonal pattern of the rainfall is only slightly different between the two stations: the rainy period is a little longer in Cinzana than in Banizoumbou, especially because the first rains occur a little sooner. Moreover, there is a continuous decrease in the amount of precipitation per rainy event from June to November in Cinzana and from July to October in Banizoumbou. The patterns of the monthly rainfall are consistent with those determined by Nicholson (2005) for the corresponding Sahelian latitude bands and those reported by Frappart et al. (2009) for various Sahelian stations.

The average time interval separating two consecutive rainy events progressively decreases from the onset of the monsoon ( 5 to 8 days in May) to the core of the monsoon period, where it reaches its minimum of 1 to 3 days (Table 1). When the monsoon begins its retreat, this interval increases again up to 6 to 10 days in October. The highest standard deviations observed for the average time interval separating two consecutive rainy events in May and to a less degree in June are, for the main part, due to some dry spells that can reach up to 20 consecutive days certain years. 



Figure 2. $(a, b)$ Average monthly number of rainy events, $(c, d)$ average monthly rainfall and $(e, f)$ average monthly rainfall per rainy event for (left) Banizoumbou and (right) Cinzana. Data recorded over the period 2006-2015 from which are excluded the years 2008, 2012 and 2014 for Banizoumbou and the years 2007, 2011 and 2013 for Cinzana (see text for explanation). The vertical bars correspond to the interannual standard deviations.

\section{Table 1}

303 Average Time Interval Between Two Rainy Events in Banizoumbou and Cinzana. Period

304 2006-2015 (Only Periods Without Sampling Gaps Between Two Rainy Events are

305 Considered) 


\begin{tabular}{lcccccc}
\hline & \multicolumn{2}{c}{ Mean } & \multicolumn{2}{c}{ Median } & \multicolumn{2}{c}{ Std } \\
\hline \multirow{3}{*}{ May } & Banizoumbou & Cinzana & Banizoumbou & Cinzana & Banizoumbou & Cinzana \\
\cline { 2 - 7 } June & 5.5 & 8.0 & 5.2 & 4.3 & 5.3 & 10.1 \\
July & 4.9 & 3.9 & 4.1 & 3.2 & 4.4 & 3.2 \\
August & 3.3 & 2.4 & 2.9 & 1.9 & 2.4 & 1.9 \\
September & 2.1 & 1.7 & 1.8 & 1.4 & 1.8 & 1.3 \\
October & 2.5 & 2.6 & 2.5 & 1.9 & 2.7 & 3.2 \\
\hline
\end{tabular}

\subsection{The Phenomenology of MCS}

As mentioned above, most of the rainy events in the Sahel are associated with MCSs. We first describe the phenomenology of such systems through a typical event that occurred in Cinzana on 18 May 2006 17:00 UTC and will then discuss the general characteristics of such events based on the whole data set.

\subsubsection{A Typical Squall Line: the 18/05/2006 Event in Cinzana}

Infrared observations from satellites allow detection of convective clouds assuming that low brightness temperatures are related to convection. The $253 \mathrm{~K}$ threshold is generally selected as the highest cloud temperature associated with convection while the $213 \mathrm{~K}$ threshold is generally associated with very deep convection (e.g., Mapes \& Houze, 1993; Mathon \& Laurent, 2001).

As shown by the brightness temperatures derived from the observations performed by the Meteosat Second Generation satellite (Figure 3), the convective system that crossed Cinzana on 18 May 2006 was a squall line, i.e., a narrow band of active convective cells extending over more than 500 kilometers in the northeast/southwest direction. The temperature at some cloud tops was as low as $213 \mathrm{~K}$ suggesting that very deep convection has developped.

Figure 4 reports the meteorological data and $\mathrm{PM}_{10}$ concentration recorded at the surface during this convective event. About 15 minutes before the rain started, a sharp drop in temperature corresponding to the onset of the cold air outflow was recorded. It was accompanied by an increase of the Water Vapor Mixing Ratio (WVMR). This increase in WVMR is characteristics of the pre-monsoon period (May-June) because during the rest of the rainy season, WVMR decreases when the temperature drops as reported by Provod et al. (2016). Almost simultaneously with the drop in temperature, a sharp increase of the wind speed (from $1.3 \mathrm{~m} \mathrm{~s}^{-1}$ to $9.9 \mathrm{~m} \mathrm{~s}^{-1}$ ) occurred in less than 10 minutes. This was the consequence of the gust front associated with the propagation of the leading edge of the outflow. This increase in wind speed was more or less concomittant with a change in wind direction. From 07:00 until 12:00 (not shown) the wind direction was stable and clearly south/southwest (i.e., the direction of the monsoon flow). Then the wind direction oscillated between southwest and northeast to finally settle east a little before than the drop in temperature occurred. For this event, the duration of precipitation was relatively short $(\sim 15$ minutes) and the rainfall was low (a total of $1.6 \mathrm{~mm}$ with a maximum intensity of $12 \mathrm{~mm} \mathrm{~h}^{-1}$ during the first five minutes).

An increase of more than 2 orders of magnitude of the $\mathrm{PM}_{10}$ concentration was observed as soon as the wind speed increased to reach concentration as high as $13500 \mu \mathrm{g} \mathrm{m}^{-3}$. However, the concentration of $\mathrm{PM}_{10}$ declined quite rapidly once the rain started although high wind speed persisted. 


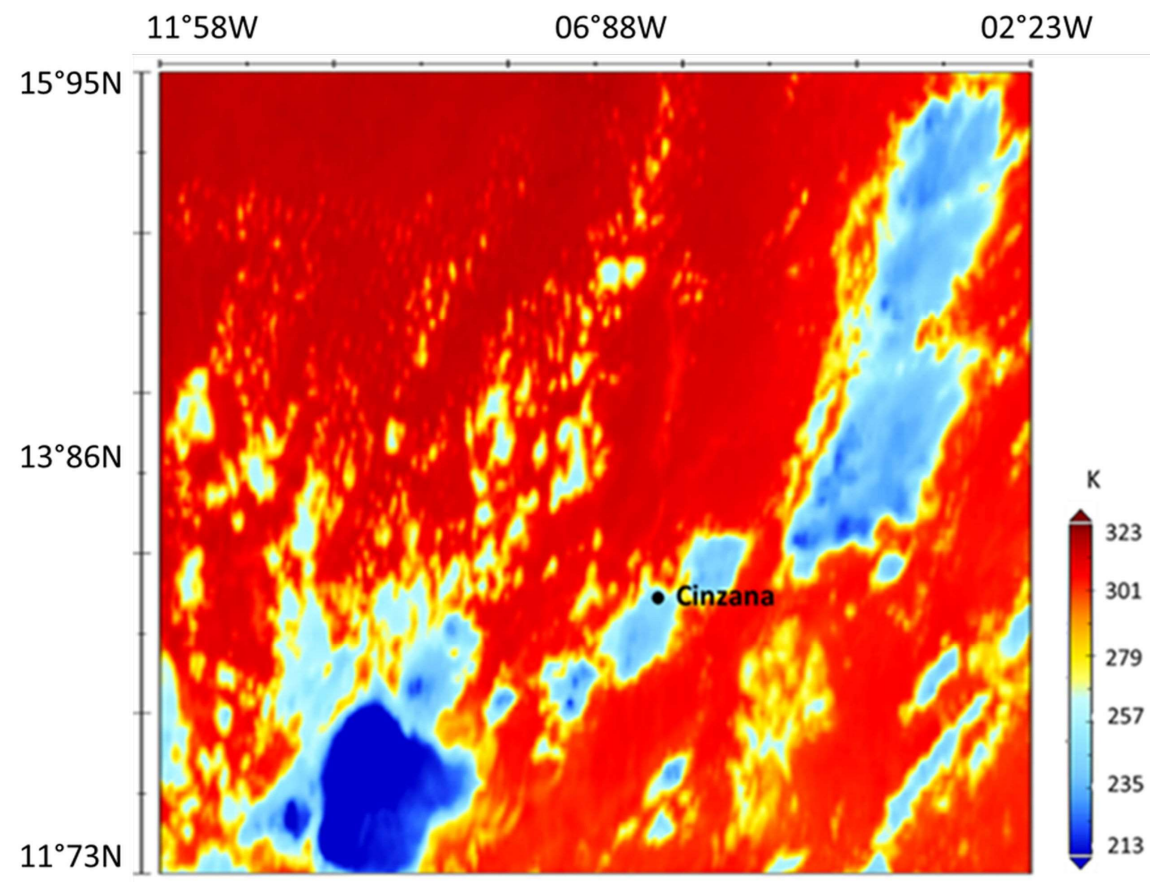

344
Figure 3. 3-km MSG SEVIRI $10.8 \mu \mathrm{m}$ channel brightness temperature imagery from 18 May 2006 17:00 UTC over the region surrounding Cinzana (Mali). The convective system is a squall line extending over about 500 kilometers in the northeast/southwest direction. The temperature of some cloud tops was close to $-213 \mathrm{~K}$ suggesting regions of very deep convection.
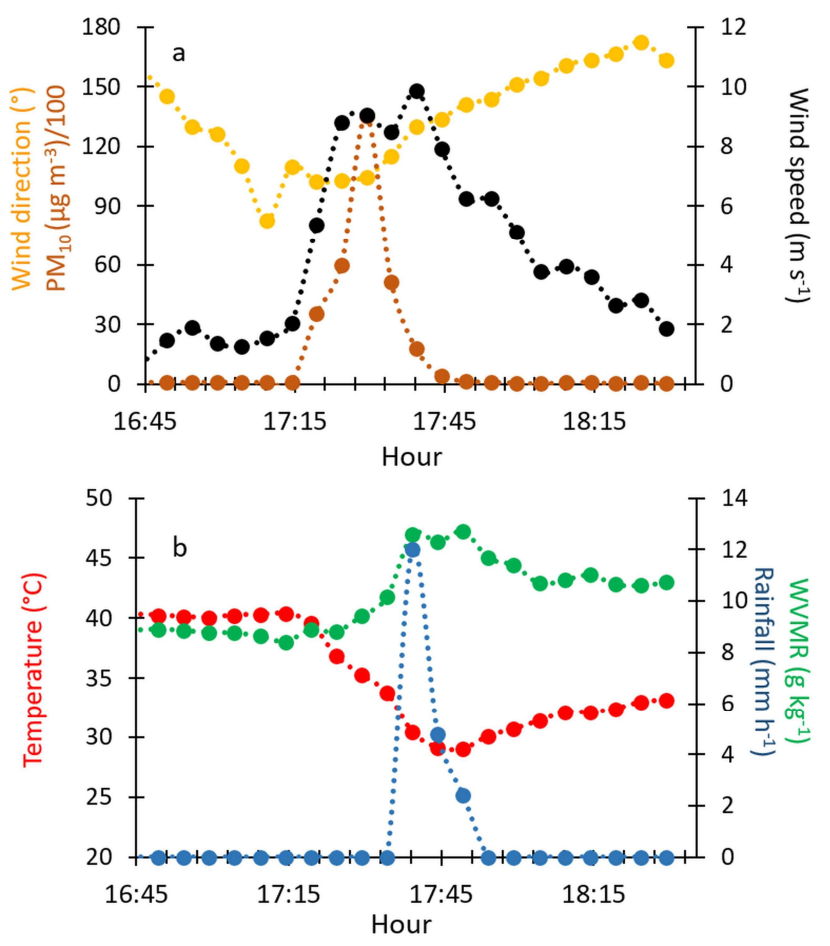
Figure 4. The 18 May 2006 convective event as recorded at the surface in Cinzana (Mali). (a) wind direction (purple), $\mathrm{PM}_{10}$ concentration (orange) and wind speed (black); (b) temperature (red), rainfall (blue) and water vapor mixing ratio (green).

\subsubsection{General Characteristics of MCSs in the Central Sahel}

The following results, based on the surface observations performed for more than 1000 rainy events, allow statistical characterization of such events. When examining the data, we observed that the time at which the onset of the cold air and that at which the gust front occurs are not always coincident as also reported by Engerer et al. (2008), Goff (1976) or Provod et al. (2016) among others. For that reason, we defined the changes in temperature, wind speed and direction during the same time period surrounding a rainy event $(+/-90$ minutes) but not necessarily exactly at the same time inside this period.

\subsubsection{Surface Wind Direction}

A change in wind direction is almost systematically oberved during the 90 minutes preceding a rainy event (Figure 5) but most frequently during the last 15-30 minutes before the rain starts. The rotation of the main surface flow is from southwest to east shifting mostly through the south. This rotation of the wind direction results from downbursts when the cumulonimbus approaches. This leads to an inversion of the direction of the flow at the surface and in the lowest layers of the troposphere (e.g., Iwashita \& Kobayashi, 2019). This change in the surface wind direction is short lived, rarely persisting more than 90 minutes after the rain has started. 

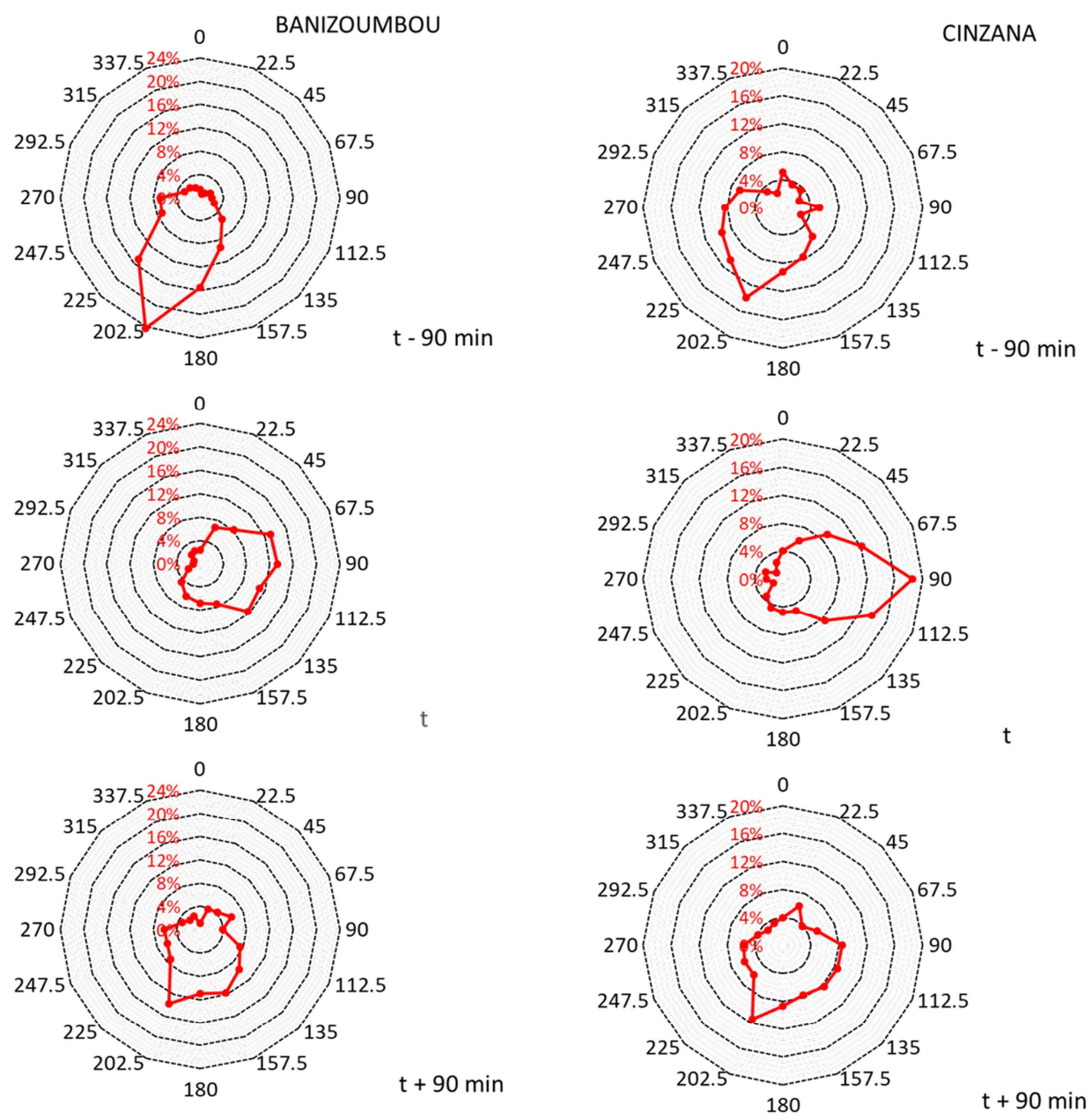

Figure 5. Wind direction 90 minutes before and after and at the onset of a rainy event $(\mathrm{t})$, in Banizoumbou (428 rainy events; no data on wind direction were available for three rainy events) and Cinzana (589 rainy events).

\subsubsection{Wind Speed and DUP}

Wind erosion and dust emission both depend on excess wind speed, raised by some power (excess wind speed is the wind speed minus the threshold wind speed). Thus, the factors controling the temporal dynamics of wind speed from minute to season also control the temporal variability of the dust emissions.

The time separating the maximum wind speed from the onset of the rain is a crucial parameter for dust emission. Indeed, once the rain has started, the soil moisture progressively increases and finally inhibits almost totally the wind erosion making high wind speed inefficient for dust emission (e.g., Bergametti et al., 2016). Furthermore, wet removal of dust particles by precipitation will limit their lifetime, and consequently their long range transport.

In Cinzana, in 58\% of cases, the maximum wind speed was recorded in the hour preceding the onset of the rainy event. In $33 \%$ of cases, the maximum wind speed was recorded in the 15 minutes prior to the start of the rain (Figure 6a). For Banizoumbou, in $63 \%$ of cases the maximum wind speed was observed in the hour preceding the onset of rain, $51 \%$ in the 30 minutes and $37 \%$ in the 15 minutes preceding the onset of rain. These results are consistent with the earlier observations performed by Byers (1949) who reported that, in convective systems, the first gust is the strongest or those by Goff (1976) who indicated that gust fronts 
speed never occurs in the 60-90 minute intervals before or after the onset of rain, underlining the short period of time during which dust emission occurs at a location where a MCS is passing by.

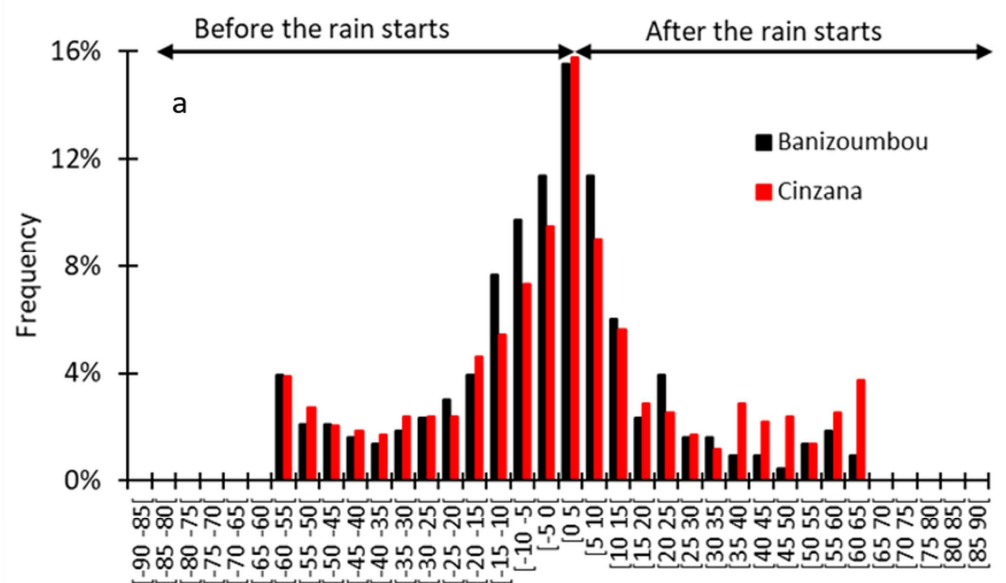

Time from the onset of the rain (minutes)

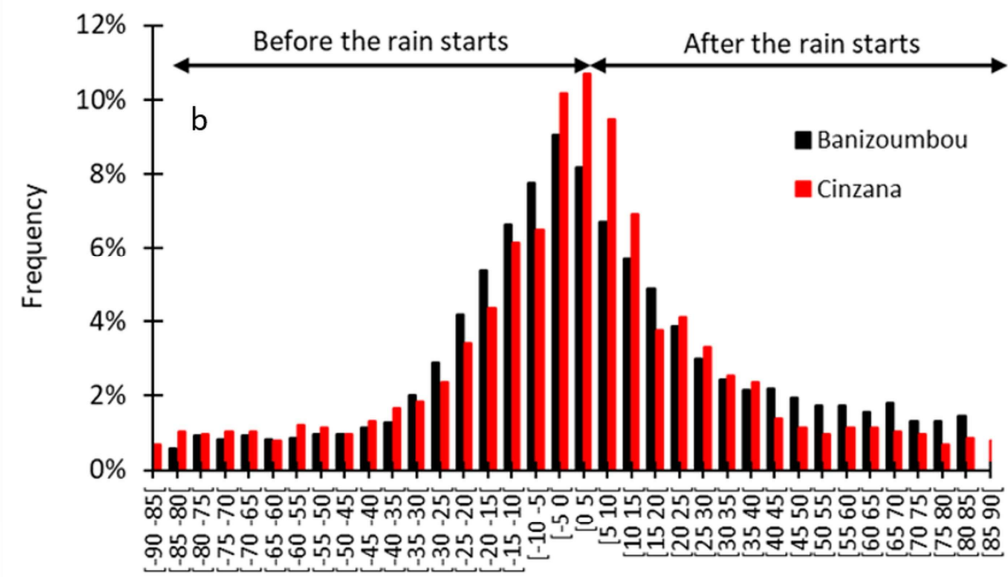

Time from the onset of the rain (minutes)

Figure 6. (a) Time of occurrence of the maximum wind speed and (b) of wind speed greater than the TWV in the period ranging from -90 minutes to +90 minutes from the onset of a rainy event for Banizoumbou (black), 431 rainy events and Cinzana (red), 589 rainy events.

Dust emission does not only depend on the magnitude of the highest wind speed but also on the duration of above-threshold wind speed. The frequency of wind speed that exceeds TWV is nearly equal before and after the rain even (Figure 6b). However, when looking at their distribution during the rainy season, we observe that wind speed exceeds the TWV during the 3 -hour time period surrounding the onset of rain $25 \%$ of the time during the pre-monsoon period. In contrast TWV is exceeded only $10 \%$ of the same time interval during the core of the monsoon.

We investigated the changes of the distribution of wind speed over a time period of 3-hour distributed evenly around the onset of the rainy event (i.e., -90 minutes/ +90 minutes encadring the onset of the rain) during the rainy season. The wind speed distribution is computed for consecutive fractions of the annual rainfall $(0-20 \%, 20-40 \%, 40-60 \%$, etc...) for both Banizoumbou and Cinzana. We favored this approach rather using fixed dates since the date of the monsoon onset varies from year to year (e.g., Sultan \& Janicot, 2003). The first $20 \%$ of the annual rainfall generally corresponds to rainy events occurring in the pre- 
monsoon period while the $80 \%$ of the annual rainfall is reached most of the time at the end of the core season, i.e., at the end of August.

Figure 7 shows that the distribution of wind speed during rainy events gradually changes throughout the rainy season. A higher frequency of the highest wind speed classes is observed during the pre-monsoon phase than during the core of the rainy season. The period corresponding to the first $20 \%$ of the rainfall represents $63.8 \%$ of the number of wind speed $\geq$ $12 \mathrm{~m} \mathrm{~s}^{-1}$ and $69 \%$ of the number of wind speed $\geq 10 \mathrm{~m} \mathrm{~s}^{-1}$ observed during the whole rainy season in Banizoumbou and in Cinzana, respectively. This prevalence during the premonsoon period of the highest wind speed associated with the rainy events is reinforced when considering that only $39 \%$ and $30 \%$ of rainy events are recorded before July 21 in Banizoumbou and Cinzana respectively (Figure 2).

Our results clearly show that the intensity of the gust fronts and their efficiency in terms of dust emission potential decrease from the onset to the core of the monsoon. Following Provod et al. (2016), we hypothezise that during the pre-monsoon phase (and to a lesser degree during its retreat), the mid-tropospheric level is drier than during the core of the monsoon which favors the evaporation of hydrometeors and thus reinforces the intensity of the cold pools and associated gusty winds.
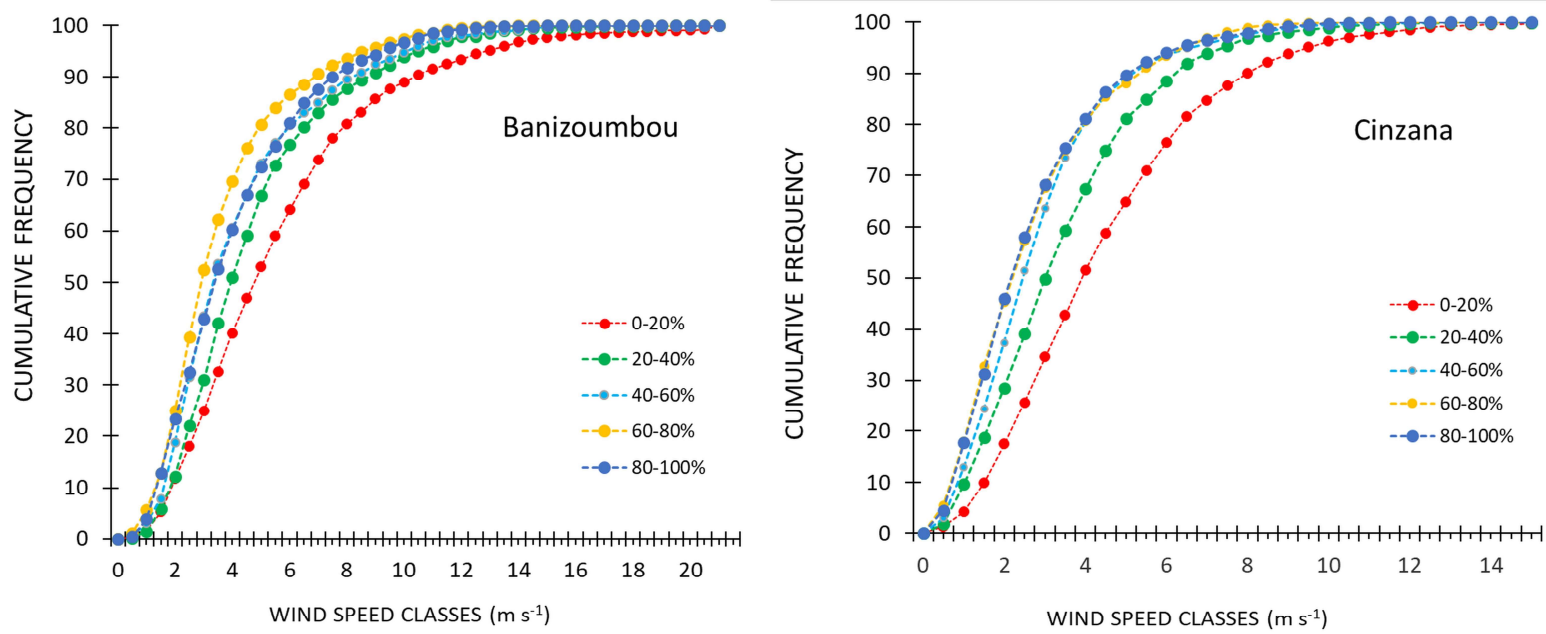

Figure 7. Distribution of surface wind speed for precipitation classes of $20 \%$ of the accumulated rainfall since the first rain of the season. The wind speed distribution is calculated from the average of the wind speed distribution during each rainy event of each precipitation class taking into account all the wind speed values preceding the onset of a rain by 90 minutes and following the onset of the same rain by 90 minutes. Only years with no notable data gaps during the period April-October are considered. There are 7 years for each series. 302 rainy events for Banizoumbou (2008, 2012 and 2014 excluded) and 449 for Cinzana (2007, 2011, 2013 excluded).

Figure 8, which reports the DUP summed over 20-day period, confirms that the contribution of the pre-monsoon period to the wind erosion and dust emission potential is dominant. Indeed, most of the DUP occurring before the 10 minutes after the commencement of rain (rain +10 minutes) is recorded before July 19 both in Banizoumbou (71\%) and Cinzana $(83 \%)$ despite only $38 \%$ and $35 \%$ of rainy events occurred before this date in Banizoumbou 
and Cinzana, respectively (Figures $8 \mathrm{c}$ and $8 \mathrm{~d})$. Moreover, most of the DUP $(67 \%$ and $74 \%$ in Banizoumbou and Cinzana, respectively) whatever the date, is produced before or in the 10 minutes following the start of the rain, i.e., a period during which the potential of wind speed for wind erosion and dust emission is not yet fully inhibited by rain (Figures $8 \mathrm{a}$ and $8 \mathrm{~b}$ ).

We conclude that the maximum wind speed intensity and frequency are associated with rainy events during the pre-monsoon period. This high wind speed mainly occurs during the dry phase of the convective event, i.e., before the rain starts. This clearly suggests that most of the high wind speed associated with such rainy events are the most efficient dust producers since they generally occur before the rain inhibits the erodability of the surface. Moreover, the prevalence of the highest wind speed in May/June has large consequences in terms of dust emission since this period of the year is that during which the soil surface is the less protected by the vegetative residues from the previous year (e.g., Abdourhamane Touré et al., 2011; Bergametti et al., 2020; Pierre et al., 2015). Thus, it can be concluded that meteorological conditions and surface characteristics converge to favor the genesis of intense wind erosion and dust emission events during the pre-monsoon period and the beginning of the monsoon.
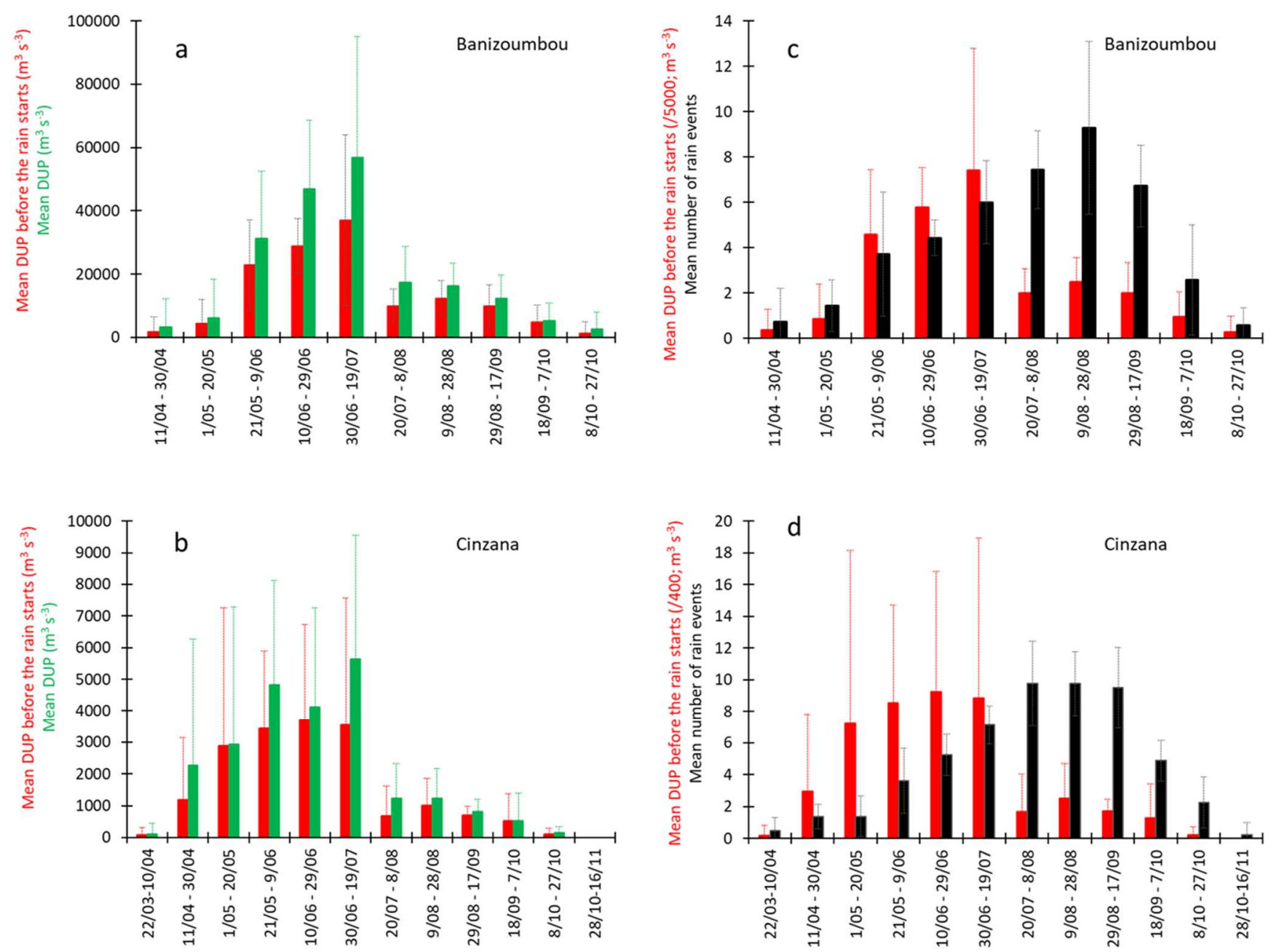

Figure 8. 20 days cumulated DUP computed as the sum of the DUP during the 90 minutes preceding the rainy event and of the DUP during the first 10 minutes of a rainy event (red): 
(a, b) mean DUP during all the whole rainy event (i.e., $+/-90$ minutes from the start of the rain, green); (c, d) mean number of rainy event (black). Means are computed over 2006-2015 excepted years 2008, 2012 and 2014 for Banizoumbou and years 2007, 2011 and 2013 for Cinzana.

\subsection{Cold Pools and Wind Speed}

Cold pools are one of the main components of the convective systems: as cooler air accumulates near the surface, the surface pressure increases hydrostatically leading to gusty winds in response to the changing surface pressure field (e.g., Provod et al., 2016; Purdom, 1976; Wilson \& Schreiber, 1986). Thus, we investigated the links between the cold pool intensity and the surface wind speed.

We use the decrease in surface air temperature as an indicator of the intensity of a cold pool. Figure 9 provides an example of surface temperature change with the passing of a squall line. When comparing with the previous day (17/05/2006) during which no rainy event occurred, the temperature on 18 May in Cinzana was identical to that on 17 May from 12:00 to about 16:30. However, on 18 May, when the rain started, the temperature dropped dramatically. About 30 minutes after the onset of the rain, the temperature was $11^{\circ} \mathrm{C}$ lower than the previous day at the same hour and the temperature anomaly was still $3.7^{\circ} \mathrm{C}$ two hours after the rain stopped.

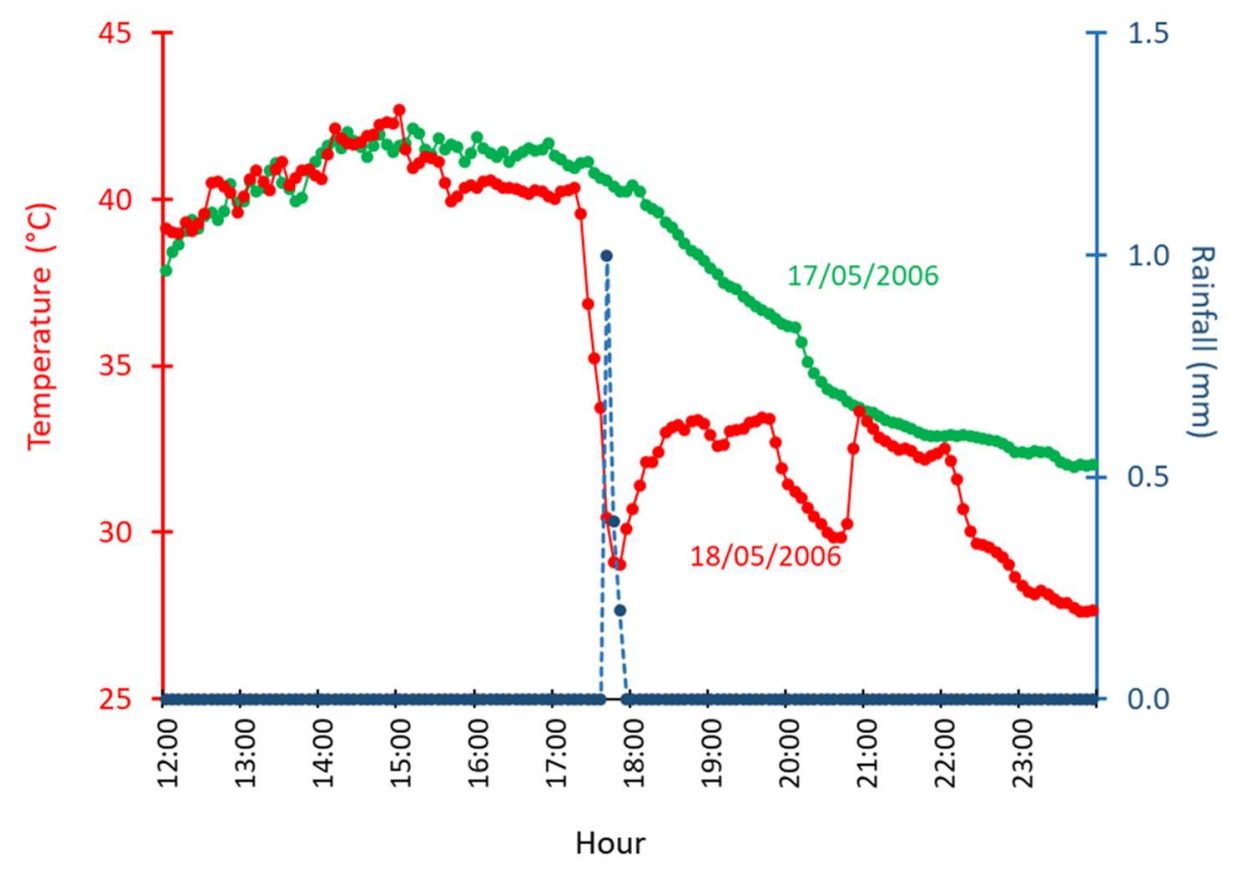

Figure 9. Decrease in temperature due to a squall line that crossed Cinzana on 18/05/2006 compared to the previous day (17/05/2006) during which no precipitation occurred; (red) temperature on 18 May 2006 ; (green) temperature on 17 May 2006; (blue) rainfall on 18 May 2006.

Thus, for each rainy event we computed the associated decrease in temperature (hereafter $\Delta T$ ) as the difference between the maximum temperature observed during the 30 minutes preceding the onset of the rain and the minimum temperature observed during the 30 minutes following the onset of the rain. Indeed, depending on the event, the maximum and minimum 
temperature can occur at different times with regards to the start of the rain (Provod et al., 2016). We also computed the change in wind speed (hereafter $\Delta U$ ) as the difference between the maximum and the minimum wind speed observed in $t+60$ minutes and $t-60$ minutes, $t$ being the time of the onset of the rain. We selected a slightly longer time window than for temperature to account for the 10 to $15 \%$ of high wind speed occuring between $30-60$ minutes before or after the rain starts (Figure 6). Lastly, we also retained the maximum wind speed averaged over a time period of 5 minutes for each rainy event and occuring inside this time interval as an other useful parameter.

The range of $\Delta T$ measured at both stations is very large. The highest observed decreases in surface temperature are $19.4^{\circ} \mathrm{C}$ and $19.8^{\circ} \mathrm{C}$ in Banizoumbou and Cinzana, respectively. Temperature decreases higher than $5^{\circ} \mathrm{C}$ are recorded for $48 \%$ (207 rainy events) and $47 \%$ (275 rainy events) of the rainy events in Banizoumbou and Cinzana, respectively. On the other hand, a significant number of rainy events appears not to be associated with intense cold pools since $26 \%$ (112 rainy events) and 25\% (147 rainy events) in Banizoumbou and Cinzana respectively, have a $\Delta T<2{ }^{\circ} \mathrm{C}$ (Figure 10).

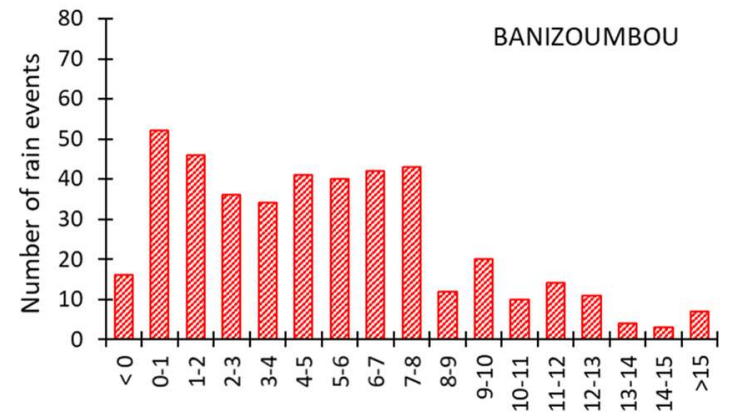

$\Delta T\left({ }^{\circ} \mathrm{C}\right)$

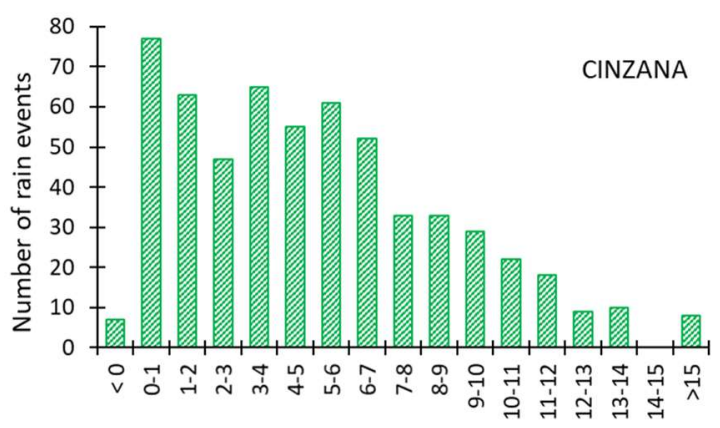

$\Delta T\left({ }^{\circ} \mathrm{C}\right)$

Figure 10. Frequency distribution of the decrease in surface temperature associated with the rainy events observed in Banizombou and Cinzana.

There is a strong linear relationship $(\alpha<0.01)$ between $\Delta T$ and $\Delta U$, as well as between $\Delta T$ and the maximum wind speed (Figure 11). This is consistent with the assumption that gust fronts have the dynamic characteristics of a density current (e.g., Knippertz et al., 2009; Wakimoto, 1982) and should move faster when the temperature drop is larger.

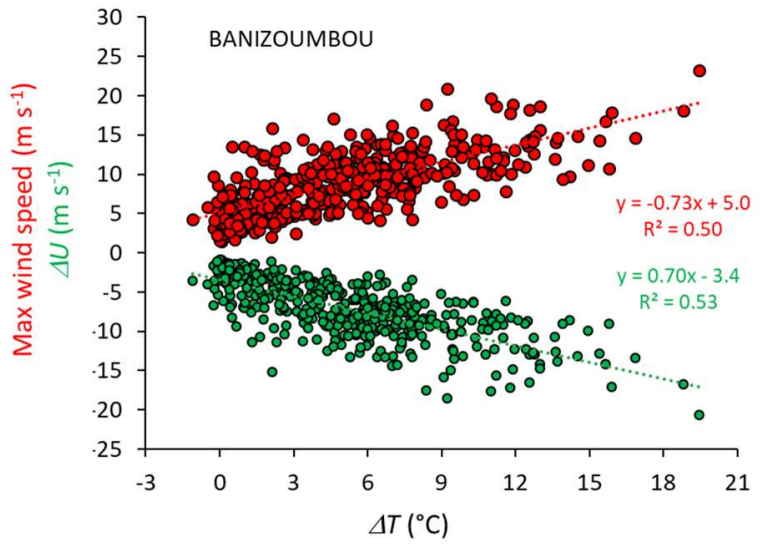

Figure 11. Relationships between $\Delta T$, the maximum wind speed (red) and $\Delta U$ (green) for Banizoumbou (432 rainy events) and Cinzana (586 rainy events).

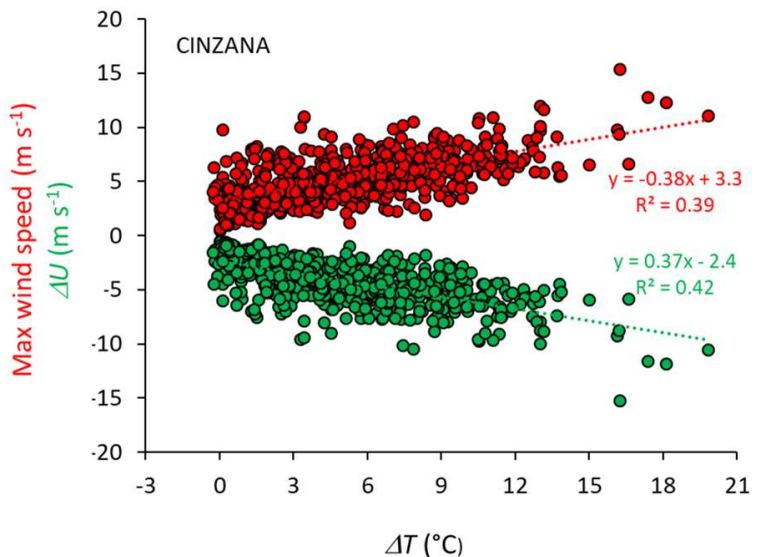

$\Delta T\left({ }^{\circ} \mathrm{C}\right)$ 
The relation between $\Delta U$ (or the maximum wind speed) with $\Delta T$ looks like a mixing line that may reflect the spectrum of structures between the convective and stratiform extremes (Mapes \& Houze, 1993; Houze, 1997). This relation is consistent with the observations performed by Taylor et al. (2017) that underlined that colder MCSs are associated with increases in propagation speed. Thus, we tried to characterize the properties of the two "endmembers" defined as: 1 - the rainy events having a $\Delta T \geq 10^{\circ} \mathrm{C}$ (49 events in Banizoumbou and 67 in Cinzana) and 2- those having a $\Delta T \leq 1^{\circ} \mathrm{C}(73$ events in Banizoumbou and 90 in Cinzana).

These two groups exhibit very different characteristics (Figure 12). Both in Banizoumbou and Cinzana, the rainy events corresponding to $\Delta T \geq 10^{\circ} \mathrm{C}$ are associated with high wind speed and dominant wind directions from E-NE. Most of them have high rainfall, and occur during the pre-monsoon period. They are more frequent in the late afternoon and early night in Banizoumbou but occur a little earlier in Cinzana. This diurnal cycle is quite similar to that observed for the occurrence of haboobs in Khartoum (Sudan) by Sutton (1931) with a peak from 18:00-20:00 local time and a quiet period from 04:00-12:00 local time. Zhang et al. (2016) and Vizy \& Cook (2017) also reported that MCS activity and rainfall frequencies peak in the evening (18:00-02:00) over most of the Sahel.

The rainy events having a $\Delta T \leq 1{ }^{\circ} \mathrm{C}$ have almost opposite characteristics (low wind speed, low rainfall and occur mainly at night during the core of the monsoon). Regarding the wind directions, there is also a strong distinction between the two groups: for example, in Banizoumbou, the wind directions associated with $\Delta T \geq 10^{\circ} \mathrm{C}$ are for $91.8 \%$ between $22^{\circ} 5$ and $180^{\circ}$ (and mainly between $67.5^{\circ}$ and $157.5^{\circ}$ ) while for $\Delta T \leq 1^{\circ} \mathrm{C} 69.9 \%$ of wind directions are between $180^{\circ}$ and $360^{\circ}$ with most of them between $180^{\circ}$ and $247.5^{\circ}$. Table 2 summarizes the differences highlighted for the two groups in Cinzana and Banizoumbou.

We also observe for both stations that the percentage of cases for which at least one 5-minute wind speed exceeds the TWV is almost $100 \%$ for the events having $\Delta T \geq 10^{\circ} \mathrm{C}$ while it is less than $20 \%$ for those having $\Delta T \leq 1^{\circ} \mathrm{C}$. The greater the decrease in temperature is, the greater the probability to have wind speed exceeding the TWV (Figure 13).

Houze $(1997 ; 2004)$ suggests that, in the tropics, the cumulonimbus contain an evolving pattern of newer and older precipitation, the younger part of the cumulonimbus being associated with violent updrafts while in the older part the vertical air motions are generally weaker, leading to precipitation viewed as stratiform. The very different characteristics of the two groups suggest that events with large $\Delta T$ correspond to the convective phase of the rainy events while those having $\Delta T \leq 1^{\circ} \mathrm{C}$ could correspond to the final stratiform stage of the MCSs. Thus, we suspect that for the cases of rainy events exhibiting a $\Delta T \leq 1{ }^{\circ} \mathrm{C}$ only the region of the stratiform precipitation was recorded suggesting that the active part of some MCSs does not always cross exactly the location of the station. 

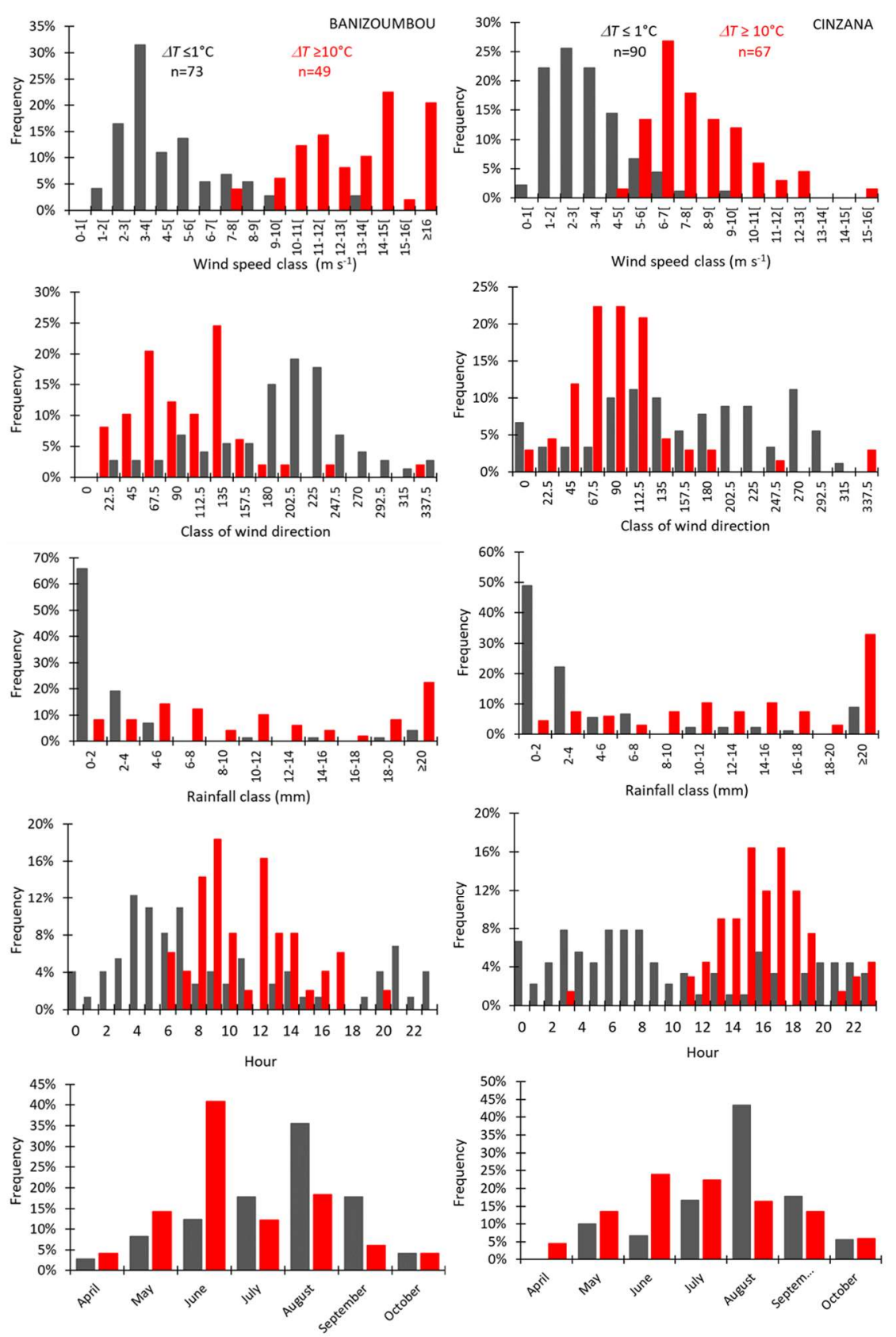

Figure 12. Frequency of maximum wind speed, wind direction, rainfall, hour and month of occurrence for the rainy events corresponding to (dark grey) $\Delta T \leq 1^{\circ} \mathrm{C}$ and (red) $\Delta T \geq 10^{\circ} \mathrm{C}$ for (left) Banizoumbou and (right) Cinzana. Wind direction and hour are those observed at the onset of the rainy event.

\section{Table 2}

568 Mean Characteristics of Rainy Events Exhibiting a $\Delta T \geq 10^{\circ} \mathrm{C}$ and $\leq 1{ }^{\circ} \mathrm{C}$ in Banizoumbou and Cinzana

\begin{tabular}{cccccc}
\hline & \multicolumn{2}{c}{ Banizoumbou } & \multicolumn{2}{c}{ Cinzana } \\
\hline & $\Delta T \geq 10^{\circ} \mathrm{C}$ & $\Delta T \leq 1^{\circ} \mathrm{C}$ & \multicolumn{2}{c}{$\Delta T \geq 10^{\circ} \mathrm{C}$} & $\Delta T \leq 1^{\circ} \mathrm{C}$ \\
\cline { 2 - 5 } Max Wind speed $\left(\mathrm{m} \mathrm{s}^{-1}\right)$ & $14-15$ & $3-4$ & $6-7$ & $2-3$
\end{tabular}


$\Delta U\left(\mathrm{~m} \mathrm{~s}^{-1}\right)$

Wind direction $\left({ }^{\circ}\right)$

67.5-135

180-270

67.5-135

none

Month

June

August

June

August

Hour

16:00-22:00 04:00-07:00

15:00-18:00 03:00-07:00

Rainfall (mm)

$>10$

$<2$

$>10$

$<2$

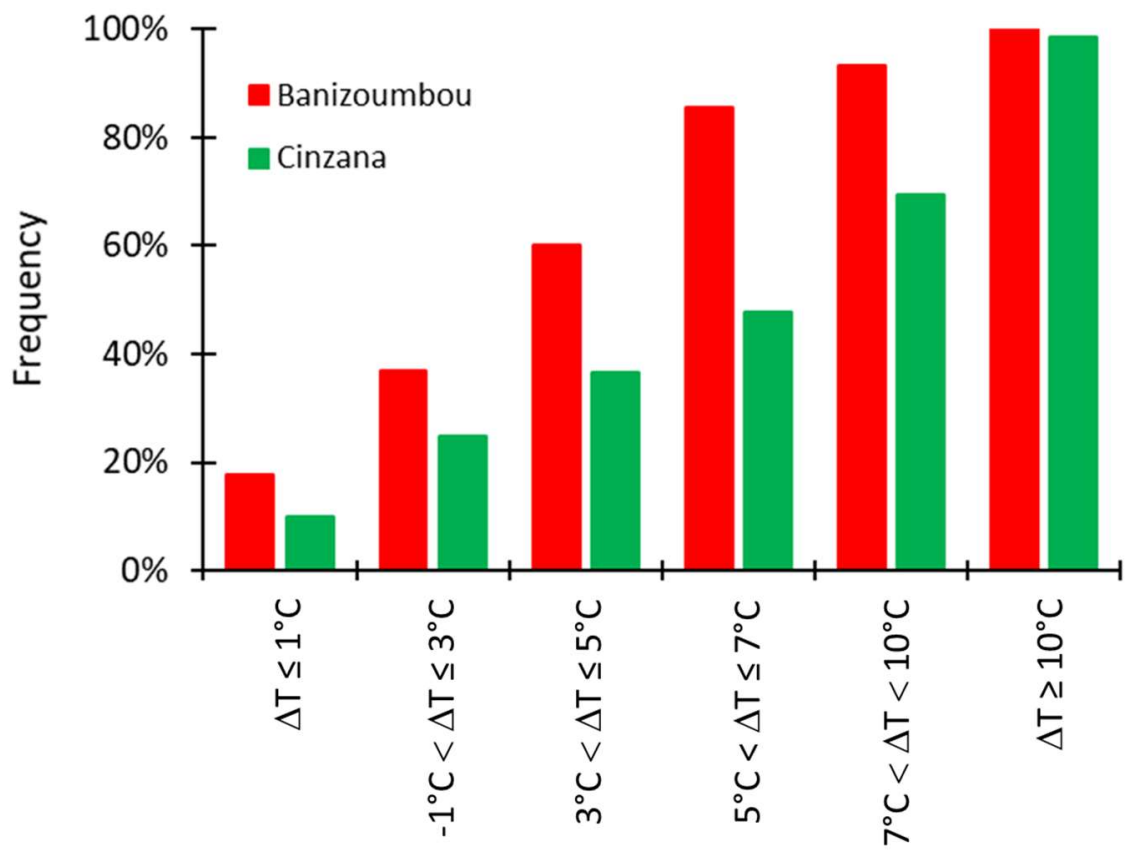

Figure 13. Percentages of rainy events for which at least one 5-minute wind speed (during the period +/- 90 minutes surrounding the onset of the rain event) exceeds the TWV depending on the $\Delta T$ class.

\subsection{High Wind Speed Events of Rainy Season Occurring Without Rainfall}

We observed that strong wind speed not linked to NLLJ occurs during the rainy season despite the absence of recorded precipitation at the stations. However, accounting for the local character of our stations and for the limited size of the MCSs, such high wind speed events could nevertheless be related to the passing of MCSs in the area surrounding the stations. To check if precipitation has occurred in the Banizoumbou area during the selected "dry" high wind speed events, we used rainfall data collected in 2006 and 2007 by the AMMA-Catch/LOP rain gauge network. In an area called the "Niamey square degree" (Figure S2), thirty rain gauge stations of this network recorded the rainfall with a 5-minute time step inside a circle of radius $\sim 80 \mathrm{~km}$ around Banizoumbou (e.g., Lebel et al., 2009).

The method we used consists in selecting the episodes having a wind speed $>7 \mathrm{~m} \mathrm{~s}^{-1}$ and $\Delta T>1^{\circ} \mathrm{C}$, $\Delta U>1 \mathrm{~m} \mathrm{~s}^{-1}$. It should be noted that the method to determine $\Delta T$ and $\Delta U$ was not exactly the same that the one we used previously (i.e., the start of the rain as reference time): for these "dry" episodes, $\Delta T$ and $\Delta U$ are determined using the time at which the maximum wind speed is recorded as a 
the above criteria, a number slightly lower than that of the rainy episodes during the same period (86). Using this method discarded the high wind speed linked to the breakdown of the NLLJ, since only a few selected events (10\%) occurred during the time interval 07:00-13:00 during which high wind speed linked to NLLJ occur (see Table S2).

Among the 70 "dry" episodes, 45 (i.e., 64\%) are associated with rainy events recorded in at least one station of the network. Nineteen of the 24 (79\%) dry episodes exhibiting the highest wind speed (> $10 \mathrm{~m} \mathrm{~s}^{-1}$ ) are associated with rainfall in the Banizoumbou area (Table S2). These 70 "dry" episodes have very similar characteristics to the rainy events with a strong link between wind speed and $\Delta T$ (see Figure S3), suggesting that they are for most of them due to the passing of MCS in the Banizoumbou area. It should also be noted that among the $10 \%(7)$ of selected events occurring between the 07:00-13:00 time period, only one was not associated with rain in the vicinity of Banizoumbou. This confirms that even for these morning events these high wind speed events were not directly linked to the NLLJ but rather to MCSs.

These results clearly suggest that almost all high wind speed events measured at Banizoumbou during the rainy season were the consequence of the passing of convective events even if precipitation was not recorded at the station.

\section{Wind Speed and PM10 During Rainy Events}

The $\mathrm{PM}_{10}$ concentration is an integrative parameter that results from the interaction of wind speed, surface properties (such as roughness, soil type, vegetation cover, soil moisture, etc.) and deposition processes such as wet deposition linked to precipitation. In the Sahelian rainy season, some of the surface parameters evolve with times. Indeed, the soil moisture changes rapidly when it rains, reinforcing the cohesive forces linking the soil grains together and thus increasing the TWV and reducing the frequency and intensity of dust emission (e.g., Bergametti et al., 2016; Pierre et al., 2012). Rain also scavenges suspended particles as shown on Figure 4. Thus, to rule out the effect of the rain scavenging, we eliminated the episodes for which the highest wind speed occurred after the beginning of the rain events and those that occurred less than 24 hours after the previous rain event. Precipitation also allows the growth of seasonal vegetation that increases both the surface cover and the roughness, decreasing the ability of the wind to cause wind erosion and dust emission (e.g., Bergametti et al., 2020).

Figures 14a and 14e show that maximum $\mathrm{PM}_{10}$ concentration and maximum wind speed are correlated in both Banizoumbou and Cinzana. This clearly demonstrates that the measured dust concentration results from local emissions due to the high wind speed associated with MCS. However, the dust concentration is higher during the pre-monsoon period by almost one order of magnitude, consistently with the higher frequency of high wind speed at that time compared to the core of the monsoon season (Figure 6). Similar pattern is observed between $\mathrm{PM}_{10}$ and $\Delta T$ (Figures $14 \mathrm{c}$ and $14 \mathrm{~d}$ ). These figures show that for similar wind speed, the $\mathrm{PM}_{10}$ concentration is higher in May and June and at the beginning of July compared to end of July, August, September and October. Bergametti et al. (2020), using NDVI to monitor the growth of the vegetation, suggested that the efficiency of wind for dust emission is strongly affected by the growth of the vegetation which reduces $\mathrm{PM}_{10}$ concentration up to $80 \%$ in the core and end of the rainy season. The relation between $U_{\max }$ and dust concentration (Figures 14b and 14f) shows an increase of TWV due to vegetation growth. Indeed, the TWV is close to $5-6 \mathrm{~m} \mathrm{~s}^{-1}$ in both Banizoumbou and Cinzana from May to early July while it exceeds 8-10 $\mathrm{m} \mathrm{s}^{-1}$ in August, September and October. Because of the strong link between wind speed and $\Delta T$ (Figure 11), we observe in Banizoumbou (Figure 14d) that a minimum $\Delta T$ able to initiate wind erosion can be defined (around $5^{\circ} \mathrm{C}$ ) in May, June and early July while even events having $\Delta T$ as high $8^{\circ} \mathrm{C}$ are not associated with dust emission during the August-October timeframe. However, such a pattern is not observed in Cinzana (Figure 14h) 

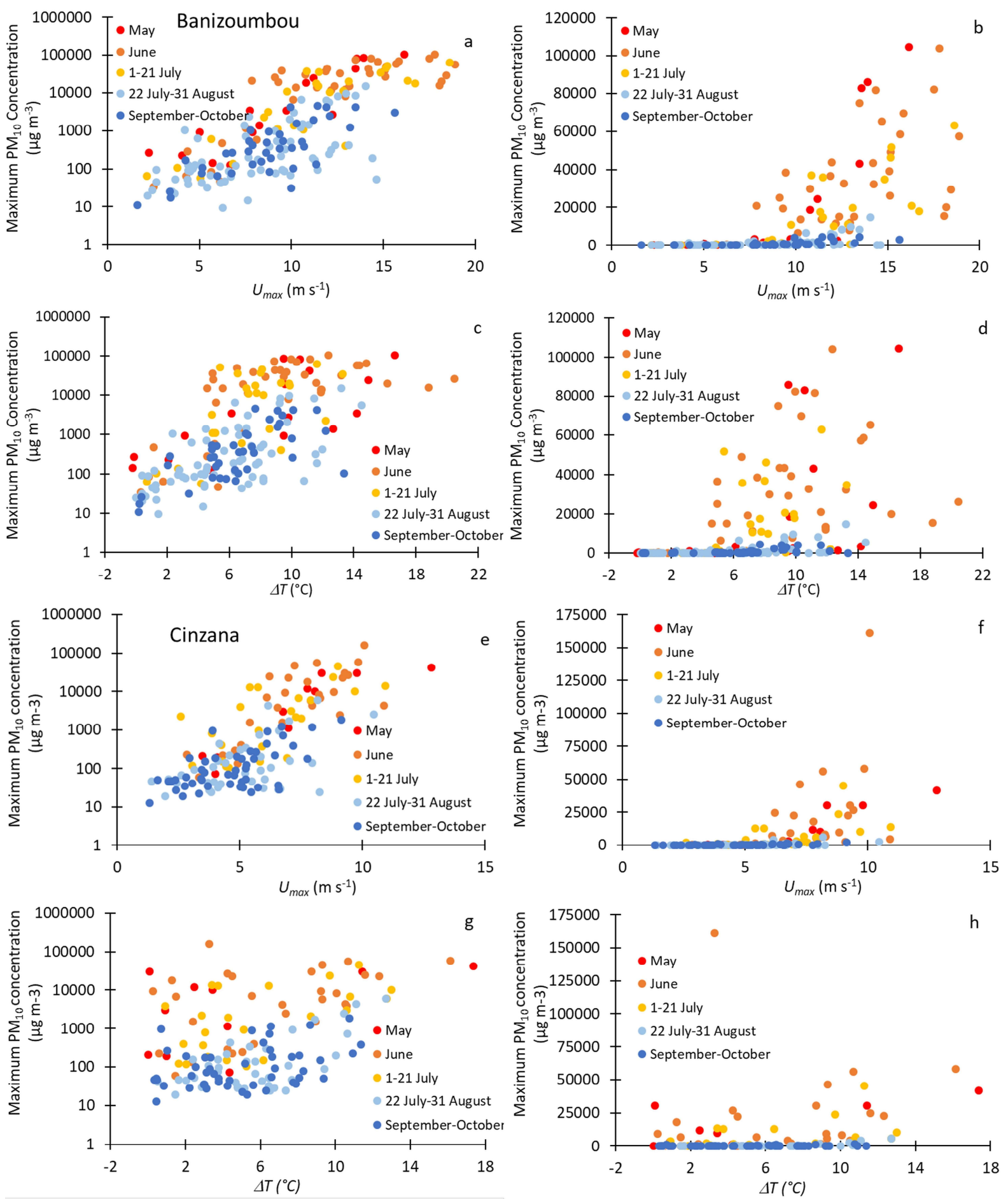

Figure 14. Links between the maximum 5-minute $\mathrm{PM}_{10}$ concentration and $U_{\max }$ and $\Delta T$ in (left) semi-log and (right) linear ; for (a-d) Banizoumbou and (e-h) Cinzana for rainy events not preceded by another rainy event in the previous 24 hours and for which $U_{\text {max }}$ is observed before the onset of the rain.

\section{Dust concentration in dry and wet season}

647 The contribution of convective events to dust emissions that occur in the wet season

648 compared to the contribution of the NLLJ in the dry season can be evaluated by looking at 
the dust concentration measured during the two seasons. Figure 15a reports for both Banizoumbou and Cinzana, over the period 2006-2015, the number of 5-minute time steps during which various thresholds in $\mathrm{PM}_{10}$ concentration $(>1000,>3000 ;>5000 ;>10000 ;>$ $30000 \mu \mathrm{g} \mathrm{m}^{-3}$ ) are exceeded for both the dry and the rainy seasons while Figure $15 \mathrm{~b}$ indicates the contribution of each season for each of these $\mathrm{PM}_{10}$ thresholds.

The highest number of 5-minute $\mathrm{PM}_{10}$ concentration exceeding the lower concentration thresholds is recorded for the dry season. However, Rajot et al. (2008), Marticorena et al. (2010) and Kaly et al. (2015) have shown that a large proportion of the highest $\mathrm{PM}_{10}$ concentration recorded during the dry season in Banizoumbou or Cinzana results from nonlocal dust advected in the Harmattan flow from the Sahara desert. This is also supported by the climatological analysis of dust pattern in North Africa based on weather reports performed by Klose et al. (2010) who concluded that most of the highest dust concentration observed in the Sahel during the dry season are due to dust transported from the Sahara. $\mathrm{PM}_{10}$ concentration exceeding $5000 \mu \mathrm{g} \mathrm{m}^{-3}$ is predominantly recorded during the rainy season. $\mathrm{PM}_{10}$ concentration exceeding $30000 \mu \mathrm{g} \mathrm{m}^{-3}$ only occurs during the rainy season and can reach $600000 \mu \mathrm{g} \mathrm{m}^{-3}$ as observed on 17 June 2006 in Banizoumbou..

These results suggest that the frequency of dust emission is higher during the dry season, due to the regular breakdown of the NLLJ in the morning but that the $\mathrm{PM}_{10}$ concentration at that time remains low. On the contrary, dust emissions during the wet season are less frequent but much more intense underlining the major role played by the MCS in controlling dust emission in the Sahel, especially those observed in the pre-monsoon period.
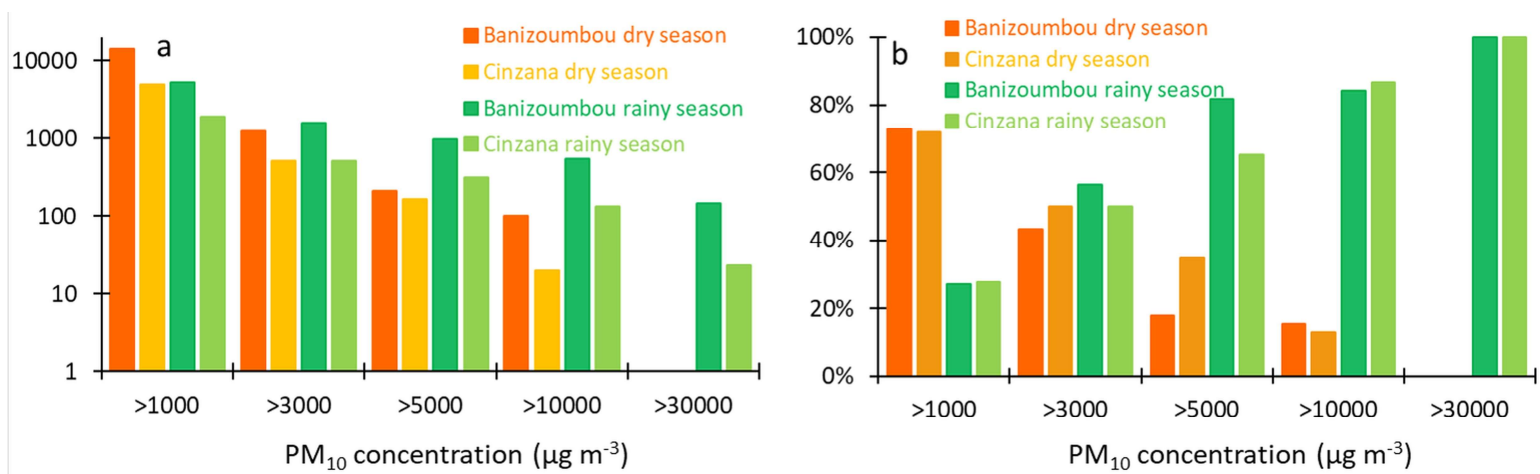

Figure 15. (a) Number of 5-minute dust concentration higher than different thresholds for the dry and rainy seasons in Banizoumbou and Cinzana and (b) relative contributions of the dry and rainy seasons to each class of 5-minute dust concentration.

\section{Conclusion}

The most intense dust emissions occur in the Sahel during the wet season and are related to the strong wind gusts that are generated ahead of the MCSs. Our results clearly show that the intensity of these strong winds (and dust emissions) is directly related to the intensity of convection which was traced by the decrease in surface temperature observed during the passage of a MCS. We have also shown that the cold pools are significantly colder at the beginning of the monsoon period when the mid-troposphere is not yet fully humidified, allowing efficient evaporation of falling droplets leading to colder downdraft. When combined with the fact that most of the highest dust concentration observed in the Sahel during the dry season are not emitted in the Sahel but are mainly dust transported from the Sahara desert (Kaly et al., 2015; Klose et al., 2010; Marticorena et al., 2010; Rajot et al. 
2008), this clearly demonstrates the importance of considering MCSs to properly assess wind erosion and dust emission in the Sahel.These results also suggest that, from a meteorological point of view, the future evolution of dust emissions in the Sahel will strongly depend on the frequency and intensity of MCSs.

The analysis of long-term precipitation records allowed the identification of long-term trends as well as the the reasons for these changes. Indeed, the analysis over the period 1950-2015 of high temporal resolution of rain gauge data for the Sahelian band by Panthou et al. (2018) highlights a trend towards more intense rainfall in the Sahel concomitant with a persisting low occurrence of rainfall events. Similarly, Taylor et al. (2017), using 35 years of Infra-Red satellite observations over the West African Sahel report a persistent increase in the frequency of the most intense (colder) MCSs and various authors argue that it is the warming of the Sahara that intensifies convection within Sahelian MCSs (e.g., Taylor et al., 2017; Shekhar \& Boos 2017; Biasutti, 2019). Although, as mentioned in the introduction, GCMs and RCMs have difficulties in simulating the future Sahelian climate, the trend towards an increasing temperature gradient between the Sahara and the Sahel is a fairly robust behaviour for the CMIP5 GCM ensemble simulations. Moreover, the models predict that this meridional gradient will strengthen throughout the $21^{\text {st }}$ century. This predicted increase in the meridional gradient and the resulting intensification of the MCSs support the idea that dust emissions occurring during the rainy season could be more intense in the future. Unfortunately, most models are unable to resolve properly MCS and therefore fail to simulate these intense Sahelian dust events, and underestimate their impacts on the Earth's climate systems.

\section{Acknowledgments}

Measurements in Banizoumbou and Cinzana are performed in the framework of the French National Observatory Services INDAAF that is supported since 2010 by the Observatoire des Sciences de l'Univers EFLUVE, the INSU/CNRS, and the IRD. The treatment of the data was performed in the framework of the research programs CAVIARS supported by the French National Agency for Research (ANR-12-SENV-0007-01) and DustClim supported by the European Commission under the ERA4CS action-Joint Call on Researching and Advancing Climate Services Development, Grant Agreement no. 690462 - ERA4CS - H2020-SC52014-2015/H2020-SC5-2015-one-stage. We also thanks AMMA-Catch for providing the rainfall data of their network. The AMMA-CATCH Environmental Research Observatory (http://www.amma-catch.org) was set up thanks to incentive funding from the French Ministry of Research. The continuity and sustainability of the measures are based on the funding granted without interruption by the IRD since 1990, and by the CNRS-INSU since 2005. The authors would like to thank the Institut d'Economie Rurale (IER) in Mali for hosting one of our stations and in particular Dr. Zoumana Kouyaté, Delegate of the Station de Recherche Agronomique de Cinzana (Mali) for the help in logistics and local management. This work has also strongly benefited from the administrative support of the representations of IRD in Niger and Mali, thanks to all of them. The authors would like to acknowledge G. S. Okin and two anonymous reviewers for their comments that helped to improve the quality of this paper.

\section{Data Availability Statement}


The wind speed and direction, rainfall and $\mathrm{PM}_{10}$ data are distributed at an hourly time resolution through the INDAAF website (https://indaaf.obs-mip.fr/database/). The data used in this manuscript are available for download for research and educational purposes at the following web link (http://www.lisa.u-pec.fr/fr/donnees) maintained by Laboratoire Interuniversitaire des Systèmes Atmosphériques.

\section{References}

Abdourhamane Touré, A., Rajot, J. L., Garba, Z., Marticorena, B., Petit, C., \& Sebag, D. (2011). Impact of very low crop residues cover on wind erosion in the Sahel. Catena, 85(3), 205-214. https://doi.org/10.1016/j.catena.2011.01.002

Abu Bakr, E. H., \& Wieringa, J. (1988). A boundary-layer model for the determination of hourly surface wind characteristics in a representative tropical African region. BoundaryLayer Meteorology, 45, 325-353. https://doi.org/10.1007/BF00124007

Allen, C. J. T., Washington, R., \& Saci, A. (2015). Dust detection from ground-based observations in the summer global dust maximum: Results from Fennec 2011 and 2012 and implications for modeling and field observations. Journal of Geophysical Research: Atmospheres, 120(3), 897-916. https://doi.org/10.1002/2014JD022655

Bergametti, G., Marticorena, B., Rajot, J.-L., Chatenet, B., Féron, A., Gaimoz, C., et al. (2017). Dust uplift potential in the central Sahel: An analysis based on 10 years of meteorological measurements at high temporal resolution. Journal of Geophysical Research: Atmospheres, 122(22), 12433-12448. https://doi.org/10.1002/2017JD027471

Bergametti, G., Marticorena, B., Rajot, J.-L., Siour, G., Féron, A., Gaimoz, et al. (2020). The respective roles of wind speed and green vegetation in controlling Sahelian dust emission during the wet season. Geophysical Research Letters, 47(22), e2020GL089761, https://doi.org/10.1029/2020GL089761

Bergametti, G., Rajot, J.-L., Pierre, C., Bouet, C., \& Marticorena, B. (2016). How long does precipitation inhibit wind erosion in the Sahel? Geophysical Research Letters, 43(12), 66436649, https://doi.org/10.1002/2016GL069324

Bergametti, G., Remoudaki, E., Losno, R., Steiner, E., Chatenet, B. \& Buat-Ménard, P. (1992). Source, transport and deposition of atmospheric phosphorus over the Northwestern Mediterranean. Journal of Atmospheric Chemistry, 14, 501-513. https://doi.org/10.1007/BF00115254

Biasutti, M. (2019). Rainfall trends in the African Sahel: characteristics, processes, and causes. Wires Climate Change, 10(4), e591. https://doi.org/10.1002/wcc.591

Boucher, O., Randall, D., Artaxo, P., Bretherton, C., Feingold, G., Forster, et al. (Eds.), Climate change 2013: The physical basis. Contribution of Working Group I to the Fifth Assessment Report of the Intergovernmental Panel on Climate Change. (pp. 571-657). Cambridge, U.K., and New York, NY: Cambridge University Press. https://doi.org/10.1017/CBO9781107415324.016

Bou Karam, D., Flamant, C., Knippertz, P., Reitebuch, O., Pelon, J., Chong, M., \& Dabas, A. (2008). Dust emissions over the Sahel associatedwith the West African monsoon intertropical 
discontinuity region: A representative case-study. Quarterly Journal of the Royal Meteorological Society, 134(632), 621-634. https://doi.org/10.1002/qj.244

Bou Karam, D., Flamant, C., Tulet, P., Todd, M., Pelon, J., \& Williams, E. (2009). Dry cyclogenesis and dust mobilization in the Inter Tropical Discontinuity of the West African Monsoon: A case study. Journal of Geophysical Research: Atmospheres, 114(D5), D05115. https://doi.org/10.1029/2008JD010952

Bukowski, J. \& van den Heever, S. C. (2020). Convective distribution of dust over the Arabian Peninsula: the impact of model resolution. Atmospheric Chemistry \& Physics, 20, 2967-2986. https://doi.org/10.5194/acp-20-2967-2020

Byers, H. R. (1949). Structure and dynamics of the thunderstorm. Science, 110(2856), 291294. https://www.jstor.org/stable/1676142

Chong, M. (2010). The 11 August 2006 squall-line system as observed from MIT Doppler radar during the AMMA SOP. Quarterly Journal of the Royal Meteorological Society, 136(S1), 209-226. https://doi.org/10.1002/qj.466

Crumeyrolle, S, Gomes, L, Tulet, P, Matsuki, A, Schwarzenboeck, A, \& Crahan, K. (2008). Increase of the aerosol hygroscopicity by aqueous mixing in a mesoscale convective system: A case study from the AMMA campaign. Atmospheric Chemistry \& Physics, 8, 6907-6924. https://doi.org/10.5194/acp-8-6907-2008

D'Amato, N., \& Lebel, T. (1998). On the characteristics of the rainfall events in the Sahel with a view to the analysis of climatic variability. International Journal of Climatology, 18(9), 955-974. https://doi.org/10.1002/(SICI)1097-0088(199807)18:9\%3C955::AIDJOC236\%3E3.0.CO;2-6

DeMott, P. J., Cziczo, D. J., Prenni, A. J., Murphy, D. M., Kreidenweis, S. M., Thomson, D. S., et al. (2003a). Measurements of the concentration and composition of nuclei for cirrus formation. Proceedings of the National Academy of Sciences, 100(25), 14655-14660. https://doi.org/10.1073/pnas.2532677100

DeMott, P. J., Sassen, K., Poellot, M. R., Baumgardner, D., Rogers D. C., Brooks, et al.. (2003b). African dust aerosols as atmospheric ice nuclei. Geophysical Research Letters, 30(14), 1732. https://doi.org/10.1029/2003GL017410

Devynck, J. L. (1981). Study of some Sahelian disturbances during WAMEX. GARP Special Report 37, App. 15, 16-27. (cited in Tetzlaff, G., \& Peters, M., 1988a).

Dhonneur, G. (1981). Les amas nuageux mobiles principale composante de la météorologie du Sahel. La Météorologie, 27, 75-86. http://pascalfrancis.inist.fr/vibad/index.php?action=getRecordDetail\&idt=PASCAL83X0097298

Diedhiou, A., Janicot, S., Viltard, A., de Felice, P., \& Laurent, H. (1999). Easterly wave regimes and associated convection over West Africa and tropical Atlantic: Results from the NCEP/NCAR and ECMWF reanalyses. Climate Dynamics, 15, 795-822. https://doi.org/10.1007/s003820050316

Dione, C., Lothon, M., Badiane, D., Campistron, B., Couvreux, F., Guichard, F., \& Salle, S. (2014). Phenomenology of Sahelian convection observed in Niamey during the early 
monsoon. Quarterly Journal of the Royal Meteorological Society, 140(679), 500-516. https://doi.org/10.1002/qj.2149.

Dosio, A., \& Panitz, H. J. (2016). Climate change projections for CORDEX-Africa with COSMO-CLM regional climate model and differences with the driving global climate models. Climate Dynamics, 46, 1599-1625. https://doi.org/10.1007/s00382-015-2664-4

Dosio, A., Jones, R. G., Jack, C., Lennard, C., Nikulin, G., \& Hewitson, B. (2019). What can we know about future precipitation in Africa? robustness, significance and added value of projections from a large ensemble of regional climate models. Climate Dynamics, 53, 58335858. https://doi.org/10.1007/s00382-019-04900-3

Dosio, A., Turner, A. G., Tamoffo, A. T., Sylla, M. B., Lennard, C., Jones, R. G., et al. (2020). A tale of two futures: contrasting scenarios of future precipitation for West Africa from an ensemble of regional climate models. Environmental Research Letters, 15(6), 064007. https://doi.org/10.1088/1748-9326/ab7fde

Douville, H., Salas-Melia, D., \& Tyteca, S. (2006). On the tropical origin of uncertainties in the global land precipitation response to global warming. Climate Dynamics., 26, 367-385. https://doi.org/10.1007/s00382-005-0088-2

Fiedler, S., Schepanski, K., Heinold, B., Knippertz, P., \& Tegen, I. (2013). Climatology of nocturnal low-level jets over North Africa and implications for modeling mineral dust emission. Journal of Geophysical Research: Atmospheres, 118(12), 6100-6121. https://doi.org/10.1002/jgrd.50394

Flamant, C., Knippertz, P., Parker, D., Chaboureau, J. P., Lavaysse, C., Agusti-Panareda, A., \& Kergoat, L. (2009). The impact of a mesoscale convective system cold pool on the northward propagation of the intertropical discontinuity over West Africa. Quarterly Journal of the Royal Meteorological Society, 135(638), 139-159. https://doi.org/10.1002/qi.357

Frappart, F., Hiernaux, P., Guichard, F., Mougin, E., Kergoat, L., Arjounin, M., et al. (2009). Rainfall regime across the Sahel band in the Gourma region, Mali. Journal of Hydrology, 375(1-2), 128-142. https://doi.org/10.1016/j.jhydrol.2009.03.007

Fryberger, S. G. (1979). Dune forms and wind regime in A Study of Global Sand Seas. E. D. MacKee. Ed., pp. 137-169, US Geological Survey Professional Paper 1052. Washington, D. C.: U.S. Government Printing Office.

Garcia-Carreras, L., Marsham, J., Parker, D., Bain, C., Milton, S., Saci, A., et al. (2013). The impact of convective cold pool outflows on model biases in the Sahara. Geophysical Research Letters, 40(8), 1647-1652. https://doi.org/10.1002/grl.50239

Garenne, M. (2016). La pression de la population dans les pays sahéliens francophones: Analyse des estimations et projections de population 1950-2100. Ferdi Working Paper 168, $26 \mathrm{pp}$. https://www.horizon.documentation.ird.fr/exldoc/pleins textes/divers1610/010067358.pdf

Goff, R. C. (1976). The vertical structure of thunderstorm outflows. Monthly Weather Review, 104(11), 1429-1440. https://doi.org/10.1175/15200493(1976)104<1429:VSOTO >2.0.CO;2 
849 Greeley, R., \& Iversen, J. D. (1985). Wind as a geological process on Earth, Mars, Venus and Titan. Cambridge - London - New York - New Rochelle - Melbourne - Sydney: Cambridge University Press.

Houze, R. A. Jr. (1997). Stratiform precipitation in regions of convection: a meteorological paradox? Bulletin of the American Meteorological Society, 78(10), 2179-2196. https://doi.org/10.1175/1520-0477(1997)078<2179:SPIROC >2.0.CO;2

Houze, R. A. Jr. (2004). Mesoscale convective systems. Review of Geophysics, 42, RG4003. https://doi.org/10.1029/2004RG000150

Huneeus, N., Schulz, M., Balkanski, Y., Griesfeller, J., Prospero, J. M., Kinne, S., et al. (2011). Global dust model intercomparison in AeroCom phase I. Atmospheric Chemistry and Physics, 11(15), 7781-7816. https://doi.org/10.5194/acp-11-7781-2011.

Iwashita, H., \& Kobayashi, F. (2019). Transition of meteorological variables while downburst occurrence by a high density ground surface observation network. Journal of Wind Engineering \& Industrial Aerodynamics, 184, 153-181. https://doi.org/10.1016/j.jweia.2018.10.007

Jickells, T. D., An, Z. S., Andersen, K. K., Baker, A. R., Bergametti, G., Brooks, N., et al. (2005). Global iron connections between desert dust, ocean biogeochemistry, and climate. Science, 308(5718), 67-71. https://doi.org/10.1126/science.1105959

Jickells, T. D., Boyd, P., \& Hunter, K. A. (2014). Biogeochemical Impacts of Dust on the Global Carbon Cycle. In P. Knippertz \& J. B. Stuut (Eds.), Mineral dust: A key player in the Earth system (Chap. 14, pp. 359-384). Dordrecht, Netherlands: Springer. https://doi.org/10.1007/978-94-017-8978-3_14

Kaly, F., Marticorena, B., Chatenet, B., Rajot, J.-L., Janicot, S., Niang, A., \& Ndiaye, T. (2015). Variability of mineral dust concentrations over West Africa monitored by the Sahelian Dust Transect. Atmospheric Research, 164-165, 226-241. https://doi.org/10.1016/j.atmosres.2015.05.011

Kawamura, R (1964). Study of sand movement by wind. In: Hydraulic Eng. Lab. Tech. Rep.,

Knippertz, P. (2008). Dust emissions in the west African heat trough: The role of the diurnal cycle and of extratropical disturbances. Meteorologische Zeitschrift, 17(5), 553-563. https://doi.org/10.1127/0941-2948/2008/0315

Knippertz, P., Trentmann, J., \& Seifert, A. (2009). High-resolution simulations of convective cold pools over the northwestern Sahara. Journal of Geophysical Research: Atmospheres, 114(D8), D08110. https://doi.org/10.1029/2008JD011271

Knopf, D. A., \& Koop, T. (2006). Heterogeneous nucleation of ice on surrogates of mineral dust. Journal of Geophysical Research: Atmospheres, 111(D12), D12201. https://doi.org/10.1029/2005JD006894

Laing, A. G., Fritsch, J. M., \& Negri, A. J. (1999). Contribution of mesoscale convective complexes to rainfall in Sahelian Africa: estimates from geostationary infrared and passive microwave data. Journal of Applied Meteorology, 38(7), 957-964. 
https://doi.org/10.1175/1520-0450(1999)038<0957:COMCCT>2.0.CO;2

Largeron, Y., Guichard, F., Bouniol, D., Couvreux, F., Kergoat, L., \& Marticorena, B. (2015). Can we use surface wind fields from meteorological reanalyses for Sahelian dust emission simulations? Geophysical Research Letters, 42(7), 2490-2499. https://doi.org/10.1002/2014GL062938

Laurent, H., D'Amato, N., \& Lebel, T. (1998). How important is the contribution of the mesoscale convective complexes to the Sahelian rainfall? Physics \& Chemistry of the Earth, 23(5-6), 629-633. https://doi.org/10.1016/S0079-1946(98)00099-8

Lebel T., Cappelaere, B., Galle, S., Hanan, N., Kergoat, L., Levis, S., et al. (2009). AMMACATCH studies in the Sahelian region of West-Africa: An overview. Journal of Hydrology, 375(1-2), 3-13, https://doi.org/10.1016/j.jhydrol.2009.03.020.

Li, J., Okin, G. S., Alvarez, L., \& Epstein, H. (2007). Quantitative effects of vegetation cover on wind erosion and soil nutrient loss in a desert grassland of southern New Mexico, USA. Biogeochemistry, 85, 317-332. https://doi.org/10.1007/s10533-007-9142-y

Li, J., Okin, G. S., Alvarez, L., \& Epstein, H. (2008). Effects of wind erosion on the spatial heterogeneity of soil nutrients in two desert grassland communities. Biogeochemistry, 88, 7388. https://doi.org/10.1007/s10533-008-9195-6

Livingstone, I., \& Warren, A. (1996). Aeolian geomorphology: an introduction. Harlow (U.K.): Addison Wesley Longman Ltd.

Lothon, M., Saïd, F., Lohou, F., \& Campistron, B. (2008). Observation of the diurnal cycle in the low troposphere of West Africa. Monthly Weather Review, 136(9), 3477-3500. https://doi.org/10.1175/2008MWR2427.1

Lothon, M., Campistron, B., Chong, M., Couvreux, F., Guichard, F., Rio, C., \& Williams, E. (2011). Life cycle of a mesoscale circular gust front observed by a C-band Doppler radar in West Africa. Monthly Weather Review, 139(5), 1370-1388. https://doi.org/10.1175/2010MWR3480.1

Mahowald, N., Jickells, T. D., Baker, A.R., Artaxo, P., Benitez-Nelson, C. R., Bergametti, G., et al. (2008). Global distribution of atmospheric phosphorus sources, concentrations and deposition rates, and anthropogenic impacts. Global Biogeochemical Cycles, 22(4), GB4026, https://doi.org/10.1029/2008GB003240

Mapes, B. E., \& Houze R. A. Jr. (1993). Cloud clusters and superclusters over the oceanic warm pool. Monthly Weather Review, 121(5), 1398-1415. https://doi.org/10.1175/15200493(1993)121<1398:CCASOT>2.0.CO;2

Marsham, J. H., Knippertz, P., Dixon, N. S., Parker, D. J., \& Lister, G. M. S. (2011). The importance of the representation of deep convection for modeled dust-generating winds over West Africa during summer. Geophysical Research Letters, 38(16), L16803. https://doi.org/10.1029/2011GL048368

Marsham, J. H., Hobby, M., Allen, C. J. T., Banks, J. R., Bart, M., Brooks, B. J., et al. (2013). Meteorology and dust in the central Sahara: Observations from Fennec supersite-1 
during the June 2011 Intensive Observation Period. Journal of Geophysical Research: Atmospheres, 118(10), 4069-4089, https://doi.org/10.1002/jgrd.50211

Marticorena, B., Chatenet, B., Rajot, J.-L., Traoré, S., Coulibaly, M., Diallo, A., et al. (2010). Temporal variability of mineral dust concentrations over West Africa: Analyses of a pluriannual monitoring from the AMMA Sahelian Dust Transect. Atmospheric Chemistry and Physics, 10(18), 8899-8915. https://doi.org/10.5194/acp-10-8899-2010

Mathon, V., \& Laurent, H. (2001). Life cycle of Sahelian mesoscale convective cloud systems. Quarterly Journal of the Royal Meteorological Society, 127(572), 377-406. https://doi.org/10.1002/qj.49712757208

Mathon, V., Laurent, H., \& Lebel, T. (2002). Mesoscale convective system rainfall in the Sahel. Journal of Applied Meteorology, 41(11), 1081-1092. https://doi.org/10.1175/15200450(2002)041<1081:MCSRIT>2.0.CO;2

McGraw-Herdeg, M. (2010). Dusty gust fronts and their contributions to long-lived convection in West Africa. Master of Engineering in Electrical Engineering and Computer Sciences, Department of Electrical Engineering and Computer Science, Massachusetts Institute of Technology, Dept. of Electrical Engineering and Computer Science. http://hdl.handle.net/1721.1/61173

Mekonnen, A., \& Rossow, W. B. (2018). The Interaction between deep convection and easterly wave activity over Africa: convective transitions and mechanisms. Monthly Weather Review, 146(6), 1945-1961. https://doi.org/10.1175/MWR-D-17-0217.1

Miller, R. L., Knippertz, P., Pérez García-Pando, C., Perlwitz, J. P., \& Tegen, I. (2014). Impact of dust radiative forcing upon climate. In P. Knippertz \& J. B. Stuut (Eds.), Mineral dust: A key player in the Earth system (Chap. 11, pp. 327-357). Dordrecht, Netherlands: Springer. https://doi.org/10.1007/978-94-017-8978-3 11

Min, Q. L., Li, R., Lin, B., Joseph, E., Wang, S., Hu, Y., Morris, V., \& Chang, F. (2009). Evidence of mineral dust altering cloud microphysics and precipitation. Atmospheric Chemistry and Physics, 9, 3223-3231. https://doi.org/10.5194/acp-9-3223-2009

Mohr, K. I. (2004). Interannual, monthly, and regional variability in the wet season diurnal cycle of precipitation in sub-Saharan Africa. Journal of Climate, 17(12), 2441-2453. https://doi.org/10.1175/1520-0442(2004)017<2441:IMARVI>2.0.CO;2

Monerie, P. A., Wainwright, C. M., Sidibe, M., \& Akinsanola, A. A. (2020). Model uncertainties in climate change impacts on Sahel precipitation in ensembles of CMIP5 and CMIP6 simulations. Climate Dynamics, 55, 1385-1401, https://doi.org/10.1007/s00382-020$\underline{05332-0}$

Nicholson, S. (2005). On the question of the "recovery" of the rains in the West African Sahel. Journal of Arid Environments, 63(3), 615-641.

https://doi.org/10.1016/j.jaridenv.2005.03.004

N'Tchayi Mbourou, G. T., Bertrand, J. J., \& Nicholson, S. E. (1997). The diurnal and seasonal cycles of wind-borne dust over Africa north of the Equator. Journal of Applied Meteorology and Climatology, 36(7), 868-882. https://doi.org/10.1175/15200450(1997)036<0868: TDASCO >2.0.CO;2 
970 Okin, G. S., Mahowald, N., Chadwick, O. A., \& Artaxo, P. (2004). Impact of desert dust on the biogeochemistry of phosphorus in terrestrial ecosystems. Global Biogeochemical Cycles, 18(2), GB2005, https://doi.org/10.1029/2003GB002145

Pantillon, F., Knippertz, P., Marsham, J. H., Panitz, H.-J., \& Bischoff-Gauss, I. (2016).

Modeling haboob dust storms in large-scale weather and climate models. Journal of

Geophysical Research: Atmospheres, 121(5), 2090-2109.

https://doi.org/10.1002/2015JD024349

Pierre, C., Bergametti, G., Marticorena, B., Mougin, E., Bouet, C., \& Schmechtig, C. (2012). Impact of vegetation and soil moisture seasonal dynamics on dust emissions over the Sahel. Journal of Geophysical Research: Atmospheres, 117(D6), D06114. https://doi.org/10.1029/2011JD016950.

Pierre, C., Kergoat, L., Bergametti, G., Mougin, E., Baron, C., Abdourhamane Touré, A., et al. (2015). Modeling vegetation and wind erosion from a millet field and from a rangeland: Two Sahelian case studies. Aeolian Research, 19, 97-111. https://doi.org/10.1016/j.aeolia.2015.09.009

Provod, K., Marsham, J. H., Parker, D. J., \& Birch, C. E. (2016). A characterization of cold pools in the West African Sahel. Monthly Weather Review, 144(5), 1923-1934. https://doi.org/10.1175/MWR-D-15-0023.1

Purdom, J. F. W. (1976). Some uses of high-resolution GOES imagery in the mesoscale forecasting of convection and its behavior. Monthly Weather Review, 104(12), 1474-1483. https://doi.org/10.1175/1520-0493(1976)104<1474:SUOHRG>2.0.CO;2

Rajot, J. L., Formenti P., Alfaro, S., Desboeufs, K., Chevaillier, S., Chatenet, B., et al. (2008). AMMA dust experiment: An overview of measurements performed during the dry season special observation period (SOP0) at the Banizoumbou (Niger) supersite. Journal of Geophysical Research: Atmospheres, 113(D23), D00C14, https://doi.org/10.1029/2008JD009906

Rickenbach, T., Nieto Ferreira, R., Guy, N., \& Williams, E. (2009). Radar-observed squall line propagation and the diurnal cycle of convection in Niamey, Niger during the 2006 African Monsoon and Multidisciplinary Analyses Intensive Observing Period. Journal of Geophysical Research:Atmospheres, 114(D3), D03107. https://doi.org/10.1029/2008JD010871

Roberts, A. J., \& Knippertz, K. (2012). Haboobs: Convectively generated dust storms in West Africa. Weather, 67(12), 311-316. https://doi.org/10.1002/wea.1968

Roca, R., Aublanc, J., Chambon, P., Fiolleau, T., \& Viltard, N. (2014). Robust observational quantification of the contribution of mesoscale convective systems to rainfall in the tropics. Journal of Climate, 27(13), 4952-4958. https://doi.org/10.1175/JCLI-D-13-00628.1

Sassen, K., DeMott, P. J., Prospero, J. M., \& Poellot, M. R. (2003). Saharan dust storms and indirect aerosol effects on clouds: CRYSTAL-FACE results. Geophysical Research Letters, 30(12), 1633. https://doi.org/10.1029/2003GL017371 
1009 Semunegus, H., Mekonnen, A, \& Schreck, C. J. III. (2017). Characterization of convective

1010 systems and their association with African easterly waves. International Journal of

1011 Climatology, 37(12), 4486-4492. https://doi.org/10.1002/joc.5085

1012 Shao, Y., Wyrwoll, K.-H., Chappell, A., Huang., J., Lin, Z., McTainsh, G. H., et al. (2011).

1013 Dust cycle: an emerging core theme in Earth System Science. Aeolian Research, 2, 181-204.

1014 https://doi.org/10.1016/j.aeolia.2011.02.001

1015 Shekhar, R., \& Boos, W. R. (2017). Weakening and shifting of the Saharan shallow

1016 meridional circulation during wet years of the West African Monsoon. Journal of Climate,

1017 30, 7399-7422. doi:https ://doi.org/10.1175/JCLI-D-16-0696.1

1018 Sokolik, I. N., Winker, D. M., Bergametti, G., Gillette, D. A., Carmichael, G., Kaufman, Y.

1019 J., et al. (2001). Outstanding problems in quantifying the radiative impacts of mineral dust.

1020 Journal of Geophysical Research-Atmospheres, 106(D16), 18015-18027.

1021 https://doi.org/10.1029/2000JD900498

1022 Sterk, G. (2003). Causes, consequences and control of wind erosion in Sahelian Africa: a

1023 review. Land Degradation \& Development, 14(1), 98-108. https://doi.org/10.1002/ldr.526

1024 Sterk, G., Herrmann, L., \& Bationo, A. (1996). Wind-blown nutrient transport and soil

1025 productivity changes in Southwest Niger. Land Degradation \& Development, 7(4), 325-335.

1026 https://doi.org/10.1029/2019JD031185

1027 Sultan, B., \& Janicot, S. (2003). The west african monsoon dynamics. Part II: the "preonset"

1028 and "onset" of the summer monsoon. Journal of Climate, 16(21), 3407-3427.

1029 https://doi.org/10.1175/1520-0442(2003)016<3407:TWAMDP>2.0.CO;2

1030 Sutton, L. J. (1923). The Climate of Khartoum. Ministry of Public Works, Egypt (Cairo),

1031 Physical Department, Paper no. 9.

1032 Sutton, L. (1931). Haboobs. Quarterly Journal of the Royal Meteorological Society, 57(239),

1033 143-161. https://doi.org/10.1002/qj.49705723906

1034 Taylor, C., Belusic, D., Guichard, F., Parker, D., Vischel, T., Bock, O., et al. (2017).

1035 Frequency of extreme Sahelian storms tripled since 1982 in satellite observations. Nature,

1036 544(7651), 475-478. https://www.nature.com/articles/nature22069

1037 Taylor, K. E., Stouffer, R. J. \& Meehl, G. A. (2011). An overview of CMIP5 and the

1038 experiment design. Bulletin of the American Meteorological Society, 93, 485-498.

1039 https://doi.org/10.1175/BAMS-D-11-00094.1

1040 Tetzlaff, G., \& Peters, M. (1988a). A composite study of early summer squall lines and their 1041 environment over West Africa. Meteorology \& Atmospheric Physics, 38, 153-163.

1042 https://doi.org/10.1007/BF01029779

1043 Tetzlaff, G., \& Peters, M. (1988b). The structure of West African squall lines and their

1044 environmental moisture budget. Meteorology \& Atmospheric Physics, 39, 74-84.

1045 https://doi.org/10.1007/BF01041933

1046 Tetzlaff, G. (1982). Nordafrikanischer Passat im Winter, Berichte des Instituts fiir

1047 Meteorologie und Klimatologie der Universitit Hannover, 128pp., ISBN 3-923624-X No. 22. 
UNDP (United Nations Development Program). (2015). Population et développement au Sahel. http://undp-sahel.org/1 Rapport thématique Etude Prospective du Sahel Démographie.pdf

van Vliet, N., Reenberg, A., \& Rasmussen, L. V. (2013). Scientific documentation of crop land changes in the Sahel: A half empty box of knowledge to support policy? Journal of Arid Environment, 95, 1-13. https://doi.org/10.1016/j.jaridenv.2013.03.010

Vizy, E. K., \& Cook, K. H. (2017). Mesoscale convective systems and nocturnal rainfall over the west African Sahel: Role of the inter-tropical front. Climate Dynamics, 50, 587-614, https://doi.org/10.1007/s00382-017-3628-7

Wakimoto, R. (1982). The life cycle of thunderstorm gust fronts as viewed with Doppler radar and rawinsonde data. Monthly Weather Review, 110(8), 1060-1082. https://doi.org/10.1175/1520-0493(1982)110<1060:TLCOTG>2.0.CO;2

Weinzierl, B., Ansmann, A., Prospero, J. M., Althausen, D., Benker, N., Chouza, F., et al. (2017). The Saharan aerosol long-range transport and aerosol-cloud-interaction experiment: Overview and selected highlights. Bulletin of the American Meteorological Society, 98(7), 1427-1451. https://doi.org/10.1175/BAMS-D-15-00142.1

White, B. R. (1979). Soil transport by winds on Mars. Journal of Geophysical Research-Solid Earth, 84(B9), 4643-4651, https://doi.org/10.1029/JB084iB09p04643

Williams, E. R. (2008). Comment on "Atmospheric controls on the annual cycle of North African dust" by S. Engelstaedter and R. Washington. Journal of Geophysical ResearchAtmospheres, 113(23), D23109, https://doi.org/10.1029/2008JD009930.

Williams, E., Nathou, N., Hicks, E., Pontikis, C., Russell, B., Miller, M., \& Bartholomew, M. J. (2009). The electrification of dust-lofting gust fronts ('haboobs') in the Sahel. Atmospheric Research, 91(2-4), 292-298. https://doi.org/10.1016/j.atmosres.2008.05.017

Wilson, J. W., \& Schreiber, W. E. (1986). Initiation of convective storms at radar-observed boundary-layer convergence lines. Monthly Weather Review, 114(12), 2516-2536.

https://doi.org/10.1175/1520-0493(1986)114<2516:IOCSAR>2.0.CO;2

Zhang, G., Cook, K. H., \& Vizy, E. K. (2016). The diurnal cycle of warm season rainfall over West Africa. Part I: observational analysis. Journal of Climate, 29(23), 8423-8437. https://doi.org/10.1175/JCLI-D-15-0874.1

Figure 1. The diurnal cycle of $(a, b)$ wind speed, $(c, d)$ temperature, $(e, f)$ water vapor mixing ratio at Banizoumbou (Niger) in (a, c, e) January and (b, d, f) July. Data are averaged over the period 2006-2015. Bars indicate the standard deviation over the ten years. 
1085 Figure 2. (a, b) Average monthly number of rainy events, (c, d) average monthly rainfall and 1086 (e, f) average monthly rainfall per rainy event for (left) Banizoumbou and (right) Cinzana. 1087 Averages of data recorded over the period 2006-2015 from which are excluded the years 1088 2008, 2012 and 2014 for Banizoumbou and years 2007, 2011 and 2013 for Cinzana (see text 1089 for explanation). The vertical bars correspond to the interannual standard deviations.

1090 Figure 3. 3-km MSG SEVIRI $10.8 \mu \mathrm{m}$ channel brightness temperature imagery from 18 May 10912006 17:00 UTC over the region surrounding Cinzana (Mali). The convective system is a 1092 squall line extending over about 500 kilometers in the northeast/southwest direction. The 1093 temperature of some cloud tops was close to $-213 \mathrm{~K}$ suggesting regions of very deep 1094 convection.

1095 Figure 4. The 18 May 2006 convective event as recorded at the surface in Cinzana (Mali). (a) 1096 wind direction (purple), $\mathrm{PM}_{10}$ concentration (orange) and wind speed (black); (b) temperature 1097 (red), rainfall (blue) and water vapor mixing ratio (green).

1098 Figure 5. Wind direction 90 minutes before and after and at the onset of a rainy event (t), in 1099 Banizoumbou (428 rainy events; no data on wind direction were available for three rainy 1100 events) and Cinzana (589 rainy events).

1101 Figure 6. (a) Time of occurrence of the maximum wind speed and (b) of wind speed greater 1102 than the TWV in the period ranging from -90 minutes to +90 minutes from the onset of a 1103 rainy event for Banizoumbou (black), 431 rainy events and Cinzana (red), 589 rainy events.

1104 Figure 7. Distribution of surface wind speed for precipitation classes of $20 \%$ of the 1105 accumulated rainfall since the first rain of the season. The wind speed distribution is 1106 calculated from the average of the wind speed distribution during each rainy event of each 1107 precipitation class taking into account all the wind speed values preceding the onset of a rain 1108 by 90 minutes and following the onset of the same rain by 90 minutes. Only years with no 1109 notable data gaps during the period April-October are considered. There are 7 years for each 1110 series. 302 rainy events for Banizoumbou (2008, 2012 and 2014 excluded) and 449 for 1111 Cinzana (2007, 2011, 2013 excluded).

1112 Figure 8. 20 days cumulated DUP computed as the sum of the DUP during the 90 minutes 1113 preceding the rainy event and of the DUP during the first 10 minutes of a rainy event (red): 1114 (a, b) mean DUP during all the whole rainy event (i.e., $+/-90$ minutes from the start of the 1115 rain; green); (c, d) mean number of rainy event (black). Means are computed over 2006-2015 1116 excepted years 2008, 2012 and 2014 for Banizoumbou and years 2007, 2011 and 2013 for 1117 Cinzana.

1119 Figure 9. Decrease in temperature due to a squall line that crossed Cinzana on 18/05/2006 1120 compared to the previous day (17/05/2006) during which no precipitation occurred; (red) 1121 temperature on 18 May 2006 ; (green) temperature on 17 May 2006; (blue) rainfall on 18 1122 May 2006.

1123 Figure 10. Frequency distribution of the decrease in surface temperature associated with the 1124 rainy events observed in Banizombou and Cinzana.

1125 Figure 11. Relationships between $\Delta T$, the maximum wind speed (red) and $\Delta U$ (green) for 1126 Banizoumbou (432 rainy events) and Cinzana (586 rainy events). 
1127 Figure 12. Frequency of maximum wind speed, wind direction, rainfall, hour and month of

1128 occurrence for the rainy events corresponding to (dark grey) $\Delta T \leq 1^{\circ} \mathrm{C}$ and (red) $\Delta T \geq 10^{\circ} \mathrm{C}$ 1129 for (left) Banizoumbou and (right) Cinzana. Wind direction and hour are those observed at 1130 the onset of the rainy event.

1131 Figure 13. Percentages of rainy events for which at least one 5-minute wind speed (during 1132 the period +/- 90 minutes surrounding the onset of the rain event) exceeds the TWV

1133 depending on the $\Delta T$ class.

1134 Figure 14. Links between the maximum 5-minute $\mathrm{PM}_{10}$ concentration and $U_{\max }$ and $\Delta T$ in 1135 (left) semi-log and (right) linear; for (a-d) Banizoumbou and (e-h) Cinzana for rainy 1136 events.not preceded by another rainy event in the previous 24 hours and for which $U_{\max }$ is 1137 observed before the onset of the rain.

1138 Figure 15. (a) Number of 5-minute dust concentration higher than different thresholds for the 1139 dry and rainy seasons in Banizoumbou and Cinzana and (b) relative contributions of the dry 1140 and rainy seasons to each class of 5-minute dust concentration. 
1142

1143

Table Captions

1144

1145

Table 1 Average Time Interval Between Two Rainy Events in Banizoumbou and Cinzana.

1146 Period 2006-2015 (Only Periods Without Sampling Gaps Between Two Rainy Events are 1147 Considered)

1148

1149 Table 2 Mean Characteristics of Rainy Events Exhibiting a $\Delta T \geq 10^{\circ} \mathrm{C}$ and $\leq 1{ }^{\circ} \mathrm{C}$ in

1150 Banizoumbou and Cinzana 